\title{
Badania kontrolne po leczeniu w najczęstszych nowotworach litych u dorosłych
}

\author{
Jacek Jassem ${ }^{1}$, Renata Duchnowska ${ }^{2}$, Andrzej Kawecki ${ }^{3}$, Romuald Krajewski ${ }^{3}$, \\ Maciej Krzakowski ${ }^{4}$, Radosław Mądry ${ }^{5}$, Piotr Potemski ${ }^{6}$, Piotr Rutkowski ${ }^{7}$, \\ Janusz Siebert ${ }^{8}$, Adam Windak ${ }^{9}$, Piotr Wysocki ${ }^{10}$
}

Badania kontrolne po zakończonym leczeniu onkologicznym stanowią niezbędny element całościowej opieki nad chorymi na nowotwory. Określenie optymalnego schematu badań kontrolnych z uwzględnieniem ich efektywności kosztowej ma krytyczne znaczenie kliniczne, organizacyjne i ekonomiczne. W większości nowotworów wskazanie optymalnych schematów badań kontrolnych nie jest możliwe, bowiem przeprowadzono jedynie nieliczne prospektywne badania kliniczne, dostarczające dowodów naukowych o najwyższym stopniu wiarygodności. W tej sytuacji zalecenia oparte są w większości na retrospektywnych obserwacjach lub opiniach ekspertów. W polskim piśmiennictwie brakowało dotychczas kompleksowych opracowań przedstawiających w jednolity sposób to zagadnienie. W niniejszej pracy, przygotowanej przez grono ekspertów w dziedzinie onkologii i medycyny rodzinnej, przedstawiono propozycję schematów badań kontrolnych po leczeniu w najczęstszych nowotworach litych u dorosłych.

\section{Post-treatment surveillance in most common solid malignancies in adults}

Surveillance after oncological treatment constitutes a necessary element of comprehensive cancer care. Determining optimal follow-up schedules, including their cost effectiveness, is critical on clinical, organisational and economic grounds. Owing to a lack of prospective clinical studies providing the highest level of evidence, in most cancers optimal surveillance schemes cannot be determined. Hence, currently most recommendations are based on retrospective studies and expert opinions. In Poland comprehensive and uniform recommendations on post-treatment surveillance in cancer patients are not available. This article, prepared by a group of experts in oncology and family medicine, presents a proposal for the follow-up schemes after treatment in major solid malignancies in adults.

Słowa kluczowe: nowotwory złośliwe, obserwacja po leczeniu, zalecenia Key words: malignant diseases, post-treatment surveillance, recommendations

\footnotetext{
${ }^{1}$ Katedra i Klinika Onkologii i Radioterapii, Gdański Uniwersytet Medyczny

${ }^{2}$ Klinika Onkologii, Wojskowy Instytut Medyczny w Warszawie

${ }^{3}$ Klinika Nowotworów Głowy i Szyi, Centrum Onkologii — Instytut im. Marii Skłodowskiej-Curie w Warszawie

${ }^{4}$ Klinika Nowotworów Płuca i Klatki Piersiowej, Centrum Onkologii — Instytut im. Marii Skłodowskiej-Curie w Warszawie ${ }^{5}$ Katedra i Klinika Onkologii, Uniwersytet Medyczny im. Karola Marcinkowskiego w Poznaniu

${ }^{6}$ Klinika Chemioterapii Nowotworów, Uniwersytet Medyczny w Łodzi; Szpital im. Mikołaja Kopernika w Łodzi

${ }^{7}$ Klinika Nowotworów Tkanek Miękkich, Kości i Czerniaków, Centrum Onkologii — Instytut im. Marii Skłodowskiej-Curie w Warszawie

${ }^{8}$ Katedra Medycyny Rodzinnej, Gdański Uniwersytet Medyczny

${ }^{9}$ Zakład Medycyny Rodzinnej, Collegium Medicum, Uniwersytet Jagielloński

${ }^{10}$ Klinika Onkologii, Centrum Onkologii — Instytut im. Marii Skłodowskiej-Curie w Warszawie
} 
Badania kontrolne po zakończonym leczeniu stanowią niezbędny element całościowej opieki nad chorymi na nowotwory. $U$ chorych po radykalnym leczeniu mają one na celu wykrycie nawrotu lub wtórnego nowotworu w stadium umożliwiającym podjęcie ponownego, potencjalnie skutecznego leczenia, rozpoznawanie i leczenie późnych powikłań, poradnictwo psychologiczne i społeczne oraz ocenę odległych wyników leczenia. Bardzo ważnym elementem opieki po zakończonym leczeniu onkologicznym jest również rehabilitacja fizyczna i psychiczna chorych, zwiększająca szansę ich powrotu do wszystkich ról w rodzinie i społeczeństwie. U chorych po zakończeniu paliatywnego leczenia najważniejszym celem jest w tym okresie zapewnienie możliwie dobrej jakości życia. Ważnym elementem obserwacji po leczeniu onkologicznym jest znalezienie właściwych proporcji pomiędzy oczekiwaniami pacjentów i ich rodzin a rzeczywistą wartością poszczególnych badań diagnostycznych i ich kosztami. Wzrastające oczekiwania społeczeństwa, połączone często z roszczeniowymi postawami, skłaniają lekarzy do wykonywania wielu zbędnych procedur. Równocześnie brak jednoznacznych i powszechnie akceptowanych standardów badań kontrolnych stwarza lukę w wiedzy medycznej i naraża lekarzy na oskarżenia o niezachowanie właściwej staranności. W Polsce w niektórych nowotworach nie opracowano dotychczas zaleceń dotyczących badań kontrolnych, a w innych mają one niejednolitą strukturę. Utrudnia to klinicystom prowadzenie codziennej praktyki i powoduje dużą dowolność, a także nie pozwala sformułować przejrzystych zasad finansowania tych badań.

W polskiej onkologii dokonują się obecnie systemowe zmiany, obejmujące między innymi zniesienie limitów na badania diagnostyczne oraz większy udział lekarzy podstawowej opieki zdrowotnej (POZ) w prowadzeniu chorych po zakończonym leczeniu przeciwnowotworowym (wspólne stanowisko w tej sprawie, podpisane przez naukowe towarzystwa onkologiczne i medycyny rodzinnej, dostępne jest na stronie internetowej Polskiego Towarzystwa Onkologicznego (http://www.pto.med.pl/). Istnieje zatem potrzeba opracowania jednolitych zaleceń dotyczących badań kontrolnych i stworzenia warunków do ich przestrzegania. Zalecenia te powinny zostać również zaakceptowane przez płatnika jako jeden z elementów monitorowania jakości w ochronie zdrowia i instrumentów służących racjonalizacji wydatków.

Wskazanie optymalnych schematów badań kontrolnych nie jest łatwe, bowiem w przypadku wielu nowotworów nie przeprowadzono prospektywnych badań klinicznych, które mogłyby dostarczyć dowodów naukowych o najwyższym stopniu wiarygodności. Nawet tam, gdzie takie badania w przeszłości przeprowadzono, szybki rozwój diagnostyki i leczenia nie pozwala na wierne przeniesienie uzyskanych wyników do współczesnej praktyki klinicznej.
Niniejsze opracowanie zawiera propozycję schematów badań kontrolnych w najczęstszych nowotworach litych u dorosłych i jest adresowane do onkologów, lekarzy POZ i lekarzy innych specjalności sprawujących opiekę nad chorymi po leczeniu onkologicznym. Zostało ono przygotowane przez grono specjalistów w dziedzinach onkologii i medycyny rodzinnej, przy wsparciu reprezentowanych przez nich towarzystw naukowych (Polskie Towarzystwo Onkologiczne, Polskie Towarzystwo Onkologii Klinicznej, Polskie Towarzystwo Chirurgii Onkologicznej, Polskie Towarzystwo Radioterapii Onkologicznej, Polskie Towarzystwo Medycyny Rodzinnej i Kolegium Lekarzy Rodzinnych w Polsce). W opracowaniu tym wykorzystano dostępną wiedzę na temat badań kontrolnych oraz wskazano sytuacje, w których z powodu braku dowodów z badań klinicznych propozycje oparte są na retrospektywnych obserwacjach lub opiniach ekspertów.

\section{Nowotwory narządów głowy i szyi}

W tej grupie nowotworów ryzyko niewyleczenia lub nawrotu wynosi około $20-30 \%$ w stadium wczesnym i 60$-70 \%$ w zaawansowanym [1]. Niezależnie od tego chorzy na nowotwory głowy i szyi mają zwiększone, wynoszące 3-5\% rocznie, ryzyko zachorowania na drugi, niezależny nowotwór dróg oddechowych lub górnego odcinka przewodu pokarmowego [2].

Chorzy po radykalnym leczeniu wymagają ścisłej obserwacji, bowiem wczesne rozpoznanie nawrotu lub progresji może stworzyć możliwość ponownego leczenia z radykalną intencją. U chorych z miejscowo-regionalnym nawrotem lub rozpoznaniem drugiego nowotworu głowy i szyi po radioterapii leczeniem z wyboru jest ratująca chirurgia. Rzadziej stosuje się powtórne napromienianie. Ponowne radykalne leczenie jest jednak możliwe tylko u około $20 \%$ chorych z nawrotem; u pozostałych stosuje się leczenie paliatywne lub objawowe [3].

Istotny aspekt obserwacji po radykalnym leczeniu stanowi monitorowanie odległych następstw choroby i leczenia, które mogą skutkować zaburzeniami czynnościowymi i dolegliwościami pogarszającymi jakość życia [4]. Szczególną rolę odgrywa wizyta po 3 miesiącach od zakończenia leczenia, w trakcie której należy ostatecznie ocenić jego efekt. Częstość wizyt kontrolnych oraz zakres badań diagnostycznych należy dostosować do sytuacji klinicznej (tab. I). Przez wiele lat zalecano 5-letni okres aktywnej obserwacji po leczeniu. Obecnie uważa się, że z uwagi na wysokie ryzyko zachorowania na drugi niezależny nowotwór dróg oddechowych lub górnego odcinka przewodu pokarmowego okres obserwacji nie powinien być ograniczany [5].

Wizyta kontrolna musi obejmować ocenę miejscową, regionalną oraz systemową i wymaga przeprowadzenia szczegółowego badania przedmiotowego, w tym endoskopii górnych dróg oddechowych. W celu oceny efektu prze- 
Tabela I. Zalecane badania kontrolne u chorych na nowotwory narządów głowy i szyi

\begin{tabular}{|c|c|c|c|}
\hline Rodzaj leczenia & Badania kontrolne & Częstotliwość & Uwagi \\
\hline \multirow[t]{3}{*}{ Radykalne leczenie } & $\begin{array}{l}\text { Badanie podmiotowe i przedmiotowe } \\
\text { z oceną endoskopową górnych dróg } \\
\text { oddechowych }\end{array}$ & $\begin{array}{l}\text { Co 1-2 mies. przez pierwsze pół roku } \\
\text { Co 2-3 mies. przez następne pół roku } \\
\text { Co 3-4 mies. w 2. roku } \\
\text { Co 4-6 mies. w latach 3.-5., następnie } \\
\text { co } 12 \text { mies. }\end{array}$ & $\begin{array}{l}\text { Konieczna weryfikacja histopatologiczna } \\
\text { wszystkich zmian podejrzanych } \\
\text { o nawrót/progresję nowotworu. } \\
\text { TSH* co 6-12 miesięcy, jeżeli tarczyca } \\
\text { znalazła się w obszarze napromienianym }\end{array}$ \\
\hline & TK lub MR głowy i szyi & $\begin{array}{l}\text { Po } 3 \text { mies. od zakończenia leczenia, } \\
\text { następnie tylko u chorych z objawami } \\
\text { lub nie częściej niż co } 6 \text { mies., jeżeli } \\
\text { kliniczna ocena jest niewystarczająca }\end{array}$ & $\begin{array}{l}\text { TK klatki piersiowej co } 12 \text { mies. u chorych } \\
\text { z podwyższonym ryzykiem wystąpienia } \\
\text { raka płuca (palący tytoń) }\end{array}$ \\
\hline & $\begin{array}{l}\text { USG szyi z biopsją cienkoigłową } \\
\text { podejrzanych węzłów }\end{array}$ & $\begin{array}{l}\text { U chorych z objawami nawrotu } \\
\text { w węzłach chłonnych }\end{array}$ & \\
\hline \multirow[t]{2}{*}{ Paliatywne leczenie } & Badanie podmiotowe i przedmiotowe & $\begin{array}{l}\text { 1-2 mies. po zakończeniu leczenia, } \\
\text { następnie zależnie od występowania } \\
\text { i nasilenia objawów }\end{array}$ & $\begin{array}{l}\text { Obserwacja i leczenie w zespole opieki } \\
\text { paliatywnej }\end{array}$ \\
\hline & Badania laboratoryjne i obrazowe & Według indywidualnych wskazań & $\begin{array}{l}\text { Głównie w celu wyjaśnienia przyczyny } \\
\text { uporczywych dolegliwości (zwłaszcza } \\
\text { bólu) }\end{array}$ \\
\hline
\end{tabular}

*TSH (thyroid-stimulating hormone), hormon tyreotropowy

prowadzonego leczenia na ogół konieczne jest wykonanie badania tomografii komputerowej (TK) lub magnetycznego rezonansu (MR) głowy i szyi. W dalszej obserwacji badania te powinny być wykonywane tylko u chorych z objawami; w pozostałych przypadkach kontrolne obrazowanie narządów głowy i szyi nie jest uzasadnione.

Jedynym badaniem obrazowym wykonywanym tradycyjnie w trakcie wizyt kontrolnych nie rzadziej niż raz w roku jest zdjęcie rentgenowskie (RTG) klatki piersiowej, choć nie udowodniono jego przydatności u chorych bez objawów [6]. W przypadku podejrzeń przerzutów do płuc konieczne jest wykonanie TK klatki piersiowej. Badania obrazowe innych narządów powinny być wykonywane jedynie w przypadku wystąpienia objawów lub podejrzenia wznowy nowotworu. Tylko u nielicznych chorych z uogólnionym nowotworem można zastosować chirurgiczne leczenie z radykalną intencją, w pozostałych przypadkach stosuje się leczenie paliatywne lub objawowe. Wykrycie drugiego, niezależnego nowotworu, np. raka płuca, wymaga wdrożenia odrębnego postępowania, w zależności od stopnia zaawansowania i ogólnego stanu chorego. W rakach narządów głowy i szyi nie znalazły klinicznego zastosowania markery nowotworowe [7]. Nieuzasadnione jest także regularne wykonywanie kontrolnych badań laboratoryjnych, poza oceną czynności tarczycy u chorych poddanych napromienianiu na okolicę tego gruczołu [5].

Skutki radykalnego leczenia operacyjnego, oprócz niedających się uniknąć w niektórych sytuacjach trwałych okaleczeń, występują zwykle już w okresie pooperacyjnym i z czasem się zmniejszają. Z kolei zmiany w narządach i tkankach związane z leczeniem zachowawczym, zwłaszcza radioterapią, są trudno odwracalne i mogą się nasilać. W ocenie późnych odczynów popromiennych szczególną rolę odgrywa wywiad oraz przedmiotowa ocena obszaru objętego napromienianiem. $U$ chorych leczonych z powodu raków narządów głowy i szyi skumulowane dawki leków cytotoksycznych podawanych łącznie $z$ radioterapią $w$ ramach radykalnego leczenia są na ogół niskie, zatem ryzyko późnych następstw chemioterapii jest niewielkie.

U chorych otrzymujących paliatywne leczenie najważniejsze jest utrzymanie jak najlepszej jakości życia. W tym celu należy starannie ocenić dolegliwości chorego oraz, w razie potrzeby, podjąć doraźne działania interwencyjne. Badania obrazowe mogą być wskazane w szczególnych sytuacjach, na przykład w celu ustalenia przyczyny niekontrolowanych dolegliwości.

W sytuacji braku badań o wysokiej jakości uzasadniających poszczególne zalecenia obserwacja po leczeniu nowotworu narządów głowy i szyi stanowi odzwierciedlenie zwyczajów przyjętych w ośrodkach zajmujących się ich leczeniem oraz opinii ekspertów. W związku z dużą różnorodnością nowotworów w tym regionie podkreśla się znaczenie dostosowania postępowania do indywidualnej sytuacji pacjenta [6].

\section{Pierwotne nowotwory ośrodkowego układu nerwowego}

Największą grupę pierwotnych nowotworów ośrodkowego układu nerwowego stanowią glejaki, a na drugim miejscu znajdują się oponiaki.

Zasady prowadzenia obserwacji chorych na glejaki po radykalnym leczeniu — w zależności od stopnia złośliwości według WHO — przedstawiono w tabeli II. Glejaki o II stopniu złośliwości to m.in. gwiaździaki, skąpodrzewiaki i glejaki mieszane; stopień III tworzą gwiaździaki anaplastyczne, a IV stopień - glejak wielopostaciowy. W przypadku tego ostatniego nowotworu w zasadzie nie istnieje leczenie radykalne, ponieważ wznowy dotyczą prawie 
Tabela II. Zalecane badania kontrolne u chorych na glejaki

\begin{tabular}{|c|c|c|c|}
\hline Nowotwór & Badania kontrolne & Częstotliwość & Uwagi \\
\hline \multirow[t]{3}{*}{ Glejaki II stopnia złośliwości } & $\begin{array}{l}\text { Badanie podmiotowe } \\
\text { i przedmiotowe }\end{array}$ & Co 3-6 mies. przez 5 lat, następnie co 12 mies. & $\begin{array}{l}\text { Możliwie jak najszybciej } \\
\text { należy odstawić } \\
\text { glikokortykosteroidy lub } \\
\text { zmniejszyć ich dawkę }\end{array}$ \\
\hline & Badania laboratoryjne & $\begin{array}{l}\text { Ze wskazań klinicznych (np. monitorowanie } \\
\text { toksyczności glikokortykosteroidów lub leków } \\
\text { przeciwpadaczkowych) }\end{array}$ & \\
\hline & Badania obrazowe & $\begin{array}{l}\text { MR co 3-6 mies. przez } 5 \text { lat, następnie } \\
\text { co } 12 \text { mies. }\end{array}$ & \\
\hline \multirow[t]{3}{*}{$\begin{array}{l}\text { Glejaki III lub IV stopnia } \\
\text { złośliwości }\end{array}$} & $\begin{array}{l}\text { Badanie podmiotowe } \\
\text { i przedmiotowe }\end{array}$ & Co 3-4 mies. przez 2-3 lata, następnie rzadziej & \\
\hline & Badania laboratoryjne & $\begin{array}{l}\text { Ze wskazań klinicznych (np. monitorowanie } \\
\text { przewlekłej toksyczności glikokortykosteroidów } \\
\text { lub leków przeciwpadaczkowych) }\end{array}$ & \\
\hline & Badania obrazowe & $\begin{array}{l}\text { MR 2-6 tygodni po zakończeniu radioterapii, } \\
\text { następnie co 3-4 mies. przez 2-3 lata, potem } \\
\text { rzadziej }\end{array}$ & \\
\hline \multirow[t]{3}{*}{ Oponiaki } & $\begin{array}{l}\text { Badanie podmiotowe } \\
\text { i przedmiotowe }\end{array}$ & $\begin{array}{l}\text { W } 6 . \text { i } 12 \text { mies. po leczeniu, co 6-12 mies. } \\
\text { przez } 5 \text { lat i następnie co } 2-3 \text { lata }\end{array}$ & \\
\hline & Badania laboratoryjne & Ze wskazań klinicznych & \\
\hline & Badania obrazowe & MR w schemacie j.w. & \\
\hline
\end{tabular}

wszystkich chorych, a wieloletnie przeżycia zdarzają się wyjątkowo rzadko.

Nie ma dowodów wskazujących, że prowadzenie regularnej obserwacji wpływa na poprawę rokowania u chorych na glejaki. Ogólnie przyjęte postępowanie po leczeniu złośliwego nowotworu mózgu polega na regularnych wizytach kontrolnych w ośrodku, w którym chory był leczony, z oceną stanu neurologicznego i powtarzanymi regularnie badaniami MR $[8,9]$. Celem takiego postępowania jest wczesne wykrycie progresji nowotworu oraz powikłań leczenia. Wczesne rozpoznanie ograniczonej wznowy lub progresji guza umożliwia u części chorych wykonanie ponownej resekcji i uzyskanie wydłużenia przeżycia.

Obserwacja po leczeniu oponiaków jest dostosowywana do sytuacji pacjenta i długotrwała. Zasady obserwacji opierają się na opinii ekspertów i istniejącej praktyce. U chorych po leczeniu operacyjnym głównym celem obserwacji jest wczesne wykrycie nawrotu guza, który w ciągu 5 lat występuje u kilku procent chorych po resekcji Simpson 0 i do $80-100 \%$ po resekcji Simpson 5. Wczesne wykrycie wznowy lub progresji nieusuniętego albo napromienianego guza u większości chorych z oponiakami umożliwia podjęcie dalszego leczenia. U chorych leczonych pierwotnie napromienianiem celem obserwacji jest wykrycie nowych objawów neurologicznych, które mogą być powikłaniem leczenia lub efektem wzrostu guza, a także obiektywna ocena wielkości guza. Podstawą obserwacji są badania RM z kontrastem, które wykonuje się co 3-6 miesięcy po leczeniu, co 6-12 miesięcy przez 5 lat i następnie co 2-3 lata. Ponieważ wznowy oponiaków zdarzają się nawet po kilkunastu latach, termin zakończenia obserwacji nie jest określony.
Oponiaki są często wykrywane przypadkowo i jeżeli nie powodują objawów, preferowanym sposobem postępowania jest obserwacja z powtarzanymi badaniami MR z kontrastem. Celem obserwacji jest wykrycie nowych objawów neurologicznych, powodowanych przez guz, oraz ocena, czy guz się powiększa i jak szybko. Częstość badań powinna być podobna do zalecanej w przypadku oponiaków leczonych.

Podobne zalecenia dotyczą obserwacji chorych po leczeniu innych, rzadszych łagodnych nowotworów OUN. Częstość badań musi być dostosowana do sytuacji pacjenta i zależy od wyniku pierwotnego leczenia, lokalizacji guza i jego postaci histologicznej. Z tego powodu obserwację po leczeniu nowotworów ośrodkowego układu nerwowego powinien prowadzić zespół, który leczył chorego.

\section{Nowotwory klatki piersiowej Niedrobnokomórkowy rak płuca (NDRP)}

Około 60-70\% nawrotów po doszczętnej resekcji miąższu płucnego (chorzy w stopniu li ll oraz niektórzy w stopniu IIIA) występuje w ciągu pierwszych 2-3 lat po leczeniu [10, 11].W przypadku stosowania radiochemioterapii lub radioterapii o założeniu radykalnym (stopnie IIIA i IIIB) nawrót lub progresję choroby stwierdza się najczęściej w ciągu pierwszych 18-24 miesięcy po zakończeniu leczenia [12, 13].

Wyniki retrospektywnego badania z udziałem niemal 1400 chorych poddanych resekcji miąższu płucnego z powodu NDRP wykazały, że regularne wykonywanie co 3-6 miesięcy badań TK pozwala wydłużyć czas całkowitego przeżycia w porównaniu z obserwacją z udziałem konwencjonalnej RTG [14]. Wcześniejsze obserwacje wskazywały jednocześnie na konieczność zestawienia wyników badań 
Tabela III. Zalecane badania kontrolne u chorych na nowotwory klatki piersiowej po radykalnym leczeniu

\begin{tabular}{ll}
\hline Badanie & Częstotliwość \\
\hline $\begin{array}{l}\text { Badanie podmiotowe i przedmiotowe z uwzględnieniem objawów sugerujących } \\
\text { podejrzenie nawrotu nowotworu oraz związanych z następstwami przebytego } \\
\text { leczenia* }\end{array}$ & Przez pierwsze 2 lata co 3 mies., następnie co 6 mies. \\
Badanie TK klatki piersiowej (zalecana TK niskodawkowa) & Przez pierwsze 2 lata co 3-6 mies., następnie co 12 mies. \\
Fiberoskopia (u chorych na raka płuca) oraz inne badania obrazowe i laboratoryjne & Wyłącznie według klinicznych wskazań \\
\hline
\end{tabular}

*konieczność działań zmierzających do zaprzestania palenia tytoniu

TK klatki piersiowej z obrazem klinicznym w celu zmniejszenia ryzyka nieprawdziwie dodatnich rozpoznań nawrotów [15]. Wykonywanie TK klatki piersiowej u chorych po przebytym leczeniu z powodu NDRP może ujawnić, względnie częste w tej grupie, wtórne pierwotne nowotwory płuca [16].

Dane na temat schematu badań kontrolnych chorych na miejscowo zaawansowanego NDRP, którzy otrzymali radiochemioterapię lub radioterapię, pochodzą jedynie z badań bez randomizacji lub są analizami prospektywnych badań klinicznych. Zasady postępowania w tej grupie opierają się w znacznym stopniu na ekstrapolacji zasad stosowanych u chorych po chirurgicznym leczeniu. Niewątpliwie systematyczna obserwacja daje możliwość częstszego i wcześniejszego wykrywania nawrotów miejscowych, ale jej wpływ na wskaźniki przeżycia jest niepewny.

Dostępne wyniki badań nie uzasadniają rutynowego stosowania pozytonowej emisyjnej tomografii (PET) w ramach obserwacji chorych na NDRP po radykalnym leczeniu. Nie udowodniono wartości regularnego wykonywania bronchoskopii i innych niż TK lub RTG klatki piersiowej badań obrazowych, i badania te powinny być stosowane jedynie według indywidualnych wskazań klinicznych. Nie ma również uzasadnienia wykonywanie podczas obserwacji oznaczeń stężenia markerów [17].

W ramach badań kontrolnych po leczeniu radykalnym z powodu NDRP należy zachęcać chorych do zaprzestania palenia tytoniu (czynnika o potwierdzonym niekorzystnym wpływie na rokowanie). Wartościowa jest również ocena jakości życia chorych, aczkolwiek stosowanie szczegółowych wskaźników zawartych w formularzach jest z przyczyn organizacyjnych trudne do zrealizowania w codziennej praktyce.

Schemat badań wykonywanych podczas obserwacji chorych po radykalnym leczeniu z powodu NDRP przedstawia tabela III.

\section{Drobnokomórkowy rak płuca (DRP)}

U chorych na DRP w stopniach zaawansowania I-III (choroba ograniczona do klatki piersiowej) i spełniających określone warunki kliniczne stosuje się z wyboru radiochemioterapię o radykalnym założeniu. $U$ większości chorych, nawet w przypadku uzyskania całkowitej odpowiedzi na leczenie, dochodzi do progresji, a u 5-10\% chorych z długotrwałym przeżyciem - do rozwoju wtórnego nowotworu (najczęściej NDRP). Wymienione okoliczności oraz ryzyko powikłań związanych z leczeniem uzasadniają wykonywanie podczas obserwacji badań TK klatki piersiowej, podobnie jak w przypadku NDRP (tab. III). Stanowisko to nie jest jednak oparte na wynikach prospektywnych badań z losowym doborem chorych. Okresowe wykonywanie badania TK klatki piersiowej jest szczególnie uzasadnione u chorych z całkowitą odpowiedzią nowotworu w klatce piersiowej, w bardzo dobrym stanie sprawności oraz bez przetrwałych następstw leczenia, bowiem w tej grupie w przypadku nawrotu można rozważać próbę ponownego leczenia przyczynowego [18].

\section{Obserwacja chorych na raka płuca leczonych z założeniem paliatywnym}

Obserwacja chorych na NDRP i DRP po paliatywnym leczeniu powinna być indywidualizowana. Częstość i rodzaj badań kontrolnych zależą od wyniku zastosowanego leczenia oraz charakterystyki klinicznej chorych (stan sprawności i wiek, powikłania wcześniejszego leczenia i choroby, współwystępowanie innych chorób, wydolność czynnościowa ważnych narządów i układów) oraz możliwości leczenia w przypadku wystąpienia progresji. Podstawę stanowi powtarzane co 3 miesiące dokładne badanie podmiotowe i przedmiotowe. Spośród obrazowych badań uzasadnione może być powtarzane co 3-6 miesięcy RTG klatki piersiowej (badanie TK powinno być stosowane jedynie w przypadku wątpliwych wyników badań RTG). Inne badania obrazowe i laboratoryjne mają zasadniczo uzasadnienie jedynie w przypadku wystąpienia określonych dolegliwości i objawów.

\section{Złośliwy międzybłoniak opłucnej (ZMO)}

Dotychczas nie przeprowadzono badań pozwalających określić najbardziej odpowiedni schemat obserwacji chorych na ZMO. Rodzaj i częstość badań powinny być indywidualizowane w zależności od stopnia zaawansowania choroby i założenia leczenia oraz charakterystyki klinicznej chorych (objawy nowotworu, następstwa leczenia i współwystępujące choroby). Uzasadnione wydaje się przeprowadzanie badania podmiotowego i przedmiotowego co 2-3 miesiące i badań obrazowych co 4-6 miesięcy lub w zależności od klinicznych wskazań. W przypadku ZMO wartość badania TK klatki piersiowej jest zdecydowanie wyższa od RTG [19]. W ramach diagnostyki różnicowej zmian podej- 
rzanych o nawrót po radykalnym leczeniu pomocne może być badanie PET-TK [20].

\section{Nowotwory grasicy}

Obserwacja chorych na nowotwory grasicy po radykalnym leczeniu (wycięcie z uzupełniającym napromienianiem lub bez napromieniania lub/i chemioterapią) powinno obejmować badanie podmiotowe i przedmiotowe oraz TK klatki piersiowej (tab. III) [21, 22]. Podobne badania są zalecane w obserwacji chorych leczonych paliatywnie, ale częstotliwość oceny powinna być indywidualizowana.

\section{Nowotwory układu pokarmowego}

Zasady prowadzenia obserwacji po radykalnym leczeniu chorych na najczęstsze nowotwory układu pokarmowego przedstawiono w tabeli IV. Dla większości umiejscowień są one wypadkową zaleceń towarzystw naukowych, opinii ekspertów i przyjętej praktyki klinicznej, a wpływ regularnych wizyt kontrolnych na poprawę rokowania nie jest ustalony. Szerszego omówienia wymaga natomiast postępowanie u chorych na raka jelita grubego (RJG), ponieważ dostępne dane wskazują na zasadność prowadzenia w tej grupie intensywnej obserwacji.

RJG charakteryzuje się dużą częstością nawrotów potencjalnie kwalifikujących się do leczenia o założeniu radykalnym (ograniczony rozsiew do wątroby, nawroty miejscowe). Sugeruje to, że regularna obserwacja chorych po radykalnym leczeniu (w tym wykonywanie badań obrazowych) może się przekładać na wcześniejsze wykrywanie nawrotów i związane z tym częstsze stosowanie radykalnego leczenia nawrotów, a w efekcie - na poprawę rokowania.

Metaanaliza badań z randomizacją oceniających wartość prowadzenia intensywnej, regularnej obserwacji w porównaniu z tzw. minimalną obserwacją u chorych na RJG po radykalnym leczeniu wykazała, że regularne wizyty kontrolne i wykonywanie badań dodatkowych związane jest z mniejszą ogólną umieralnością, ale nie ma istotnego wpływu na umieralność związaną z nowotworem [23]. Większa liczba badań kontrolnych i rutynowe obrazowanie wątroby w trakcie obserwacji związane były także ze zmniejszeniem ogólnej umieralności. U chorych poddanych intensywnej obserwacji ponad dwukrotnie częściej niż u chorych poddanych tzw. minimalnej obserwacji w momencie nawrotu podjęto radykalne leczenie operacyjne. Zmniejszenie ogólnej umieralności pod wpływem intensywnej obserwacji przy braku jej istotnego wpływu na umieralność związaną z RJG może oznaczać, że istotną wartością prowadzenia regularnych wizyt kontrolnych jest na przykład ogólna edukacja prozdrowotna, wykrywanie i leczenie późnych niepożądanych objawów oraz leczenie współistniejących chorób, a nie skuteczniejsze leczenie nawrotów nowotworu. Ponadto heterogenność badań objętych metaanalizą nie pozwalała na określenie, jaki powinien być optymalny schemat intensywnej obserwacji i jakie badania są niezbędne.
Kwestie te zostały częściowo wyjaśnione dzięki prospektywnemu badaniu z randomizacją, obejmującemu 1202 chorych leczonych radykalnie z powodu RJG, w którym porównano 4 rodzaje strategii badań kontrolnych: 1) oznaczanie stężenia antygenu rakowo-zarodkowego (CEA - carcino-embryonic antygen) CEA w surowicy co 3 miesiące przez 2 lata, następnie co 6 miesięcy przez 3 lata; 2) TK jamy brzusznej, miednicy i klatki piersiowej co 6 miesięcy przez 2 lata i co 12 miesięcy przez 3 lata; 3) CEA i TK łącznie; 4) minimalna obserwacja — badania tylko w razie objawów [24]. W grupach 1. i 4. możliwe było — na życzenie prowadzącego lekarza - jednorazowe wykonanie TK jamy brzusznej, miednicy i klatki piersiowej pomiędzy 12. a 18. miesiącem obserwacji. U wszystkich chorych w 1. roku wykonywano kolonoskopię i powtarzano ją po 5 latach; chorzy z grupy 2. i 3. mieli kolonoskopię także w 2. roku obserwacji. Głównym celem badania było wykazanie różnic w odsetkach chorych poddanych radykalnemu leczeniu chirurgicznemu z powodu wznowy. Częstość radykalnego leczenia operacyjnego nawrotów rzeczywiście była większa w grupach 1.-3. w porównaniu z grupą 4. (odpowiednio 6,7\%, 8\%, 6,7\% oraz 2,3\%), nie stwierdzono jednak istotnej różnicy w odsetkach zgonów. Wyniki tego badania w pewnym stopniu kwestionują obecne zalecenia, dotyczące intensywnego nadzoru, a w szczególności zasadność kojarzenia regularnej oceny obrazowej z oznaczaniem CEA. Prawdopodobnie jednorazowe wykonanie TK pomiędzy 12. a 18. miesiącem obserwacji połączone z oznaczaniem CEA co 3 miesiące przez 2 lata, a następnie co 6 miesięcy przez 3 lata może zastąpić wielokrotne badania TK. Podkreślić należy, że w odniesieniu do zmniejszenia ryzyka zgonu nie wykazano przewagi żadnej ze strategii. Niezależnie od tego zarówno ESMO - European Society for Medical Oncology, jak i - w jeszcze większym stopniu — amerykańskie (NCCN - National Comprehensive Cancer Network i ASCO - American Society of Clinical Oncology) zalecają wykonywanie u chorych na raka okrężnicy zarówno regularnych oznaczeń CEA, jak i TK jamy brzusznej [25-27].

$\mathrm{U}$ chorych na raka odbytnicy zalecenia amerykańskie proponują podobne schematy obserwacji jak u chorych na raka okrężnicy, z dodatkowym obrazowaniem miednicy oraz wykonywaniem u niektórych chorych rektosigmoidoskopii [28]. Zalecenia ESMO w raku odbytnicy obejmują jedynie wykonywanie badania podmiotowego i przedmiotowego co 6 miesięcy przez 2 lata oraz kolonoskopii w 1. roku obserwacji, a później co 5 lat [29].

\section{Rak piersi}

Głównymi celami badań kontrolnych po leczeniu z powodu raka piersi są wczesne wykrycie miejscowego i regionalnego nawrotu choroby oraz wtórnych nowotworów, obserwacja w kierunku późnych powikłań (związanych także z wcześniejszą menopauzą czy osteoporozą), poradnictwo psychologiczne i socjologiczne (w tym zalecanie fizycznej 
Tabela IV. Zalecane badania kontrolne u chorych na nowotwory układu pokarmowego

\begin{tabular}{|c|c|c|c|}
\hline Nowotwór & Badania kontrolne & Częstotliwość & Uwagi \\
\hline Rak przełyku & $\begin{array}{l}\text { Badanie podmiotowe } \\
\text { i przedmiotowe } \\
\text { Badania laboratoryjne, } \\
\text { obrazowe i endoskopia }\end{array}$ & $\begin{array}{l}\text { Co 3-6 mies. przez } 2 \text { lata, } \\
\text { następnie co } 12 \text { mies. } \\
\text { Tylko ze wskazań klinicznych }\end{array}$ & $\begin{array}{l}\text { Korzyści z prowadzenia regularnej obserwacji } \\
\text { mogą prawdopodobnie odnieść chorzy, } \\
\text { u których można zastosować operacyjne } \\
\text { leczenie miejscowego nawrotu (np. po } \\
\text { radykalnej chemioradioterapii). U pozostałych } \\
\text { chorych należy przede wszystkim oceniać } \\
\text { powikłania przebytego leczenia, w tym } \\
\text { stan odżywienia }\end{array}$ \\
\hline $\begin{array}{l}\text { Rak żołądka } \\
\text { i połączenia } \\
\text { żołądkowo- } \\
\text {-przełykowego }\end{array}$ & $\begin{array}{l}\text { Badanie podmiotowe } \\
\text { i przedmiotowe, morfologia krwi } \\
\text { Inne badania laboratoryjne, } \\
\text { obrazowe i endoskopia }\end{array}$ & $\begin{array}{l}\text { Co 3-6 mies. przez } 2 \text { lata, } \\
\text { potem co rok } \\
\text { Tylko ze wskazań klinicznych }\end{array}$ & $\begin{array}{l}\text { Nie ustalono, czy regularna obserwacja ma } \\
\text { wpływ na rokowanie. U wszystkich chorych } \\
\text { należy oceniać następstwa przebytego } \\
\text { leczenia przeciwnowotworowego, w tym } \\
\text { stan odżywienia. Uzupełnienie niedoborów } \\
\text { witaminy B12 }\end{array}$ \\
\hline $\begin{array}{l}\text { Rak trzustki i brodawki } \\
\text { Vatera }\end{array}$ & $\begin{array}{l}\text { Badanie podmiotowe } \\
\text { i przedmiotowe; oznaczenie } \\
\text { CA19.9 (tylko u chorych } \\
\text { z podwyższonym stężeniem przed } \\
\text { zabiegiem) } \\
\text { TK jamy brzusznej }\end{array}$ & $\begin{array}{l}\text { Co 3-6 mies. przez } 2 \text { lata, } \\
\text { następnie co rok }\end{array}$ & $\begin{array}{l}\text { Nie ustalono, czy wykonywanie TK lub } \\
\text { oznaczanie CA19.9 poprawia rokowanie. } \\
\text { Bardzo ważne jest rozpoznawanie } \\
\text { i leczenie następstw radykalnego leczenia } \\
\text { (np. cukrzyca, niedobór enzymów } \\
\text { trzustkowych) }\end{array}$ \\
\hline $\begin{array}{l}\text { Rak wątrobowo- } \\
\text { komórkowy }\end{array}$ & $\begin{array}{l}\text { Badanie podmiotowe } \\
\text { i przedmiotowe; AFP* (tylko } \\
\text { u chorych z podwyższonym } \\
\text { stężeniem w chwili rozpoznania); } \\
\text { TK lub MR } \\
\text { jamy brzusznej } \\
\text { TK klatki piersiowej }\end{array}$ & $\begin{array}{l}\text { Co 3-6 mies. przez } 2 \text { lata, } \\
\text { następnie co 6-12 mies. }\end{array}$ & $\begin{array}{l}\text { Nie ustalono, czy regularne wykonywanie } \\
\text { badań obrazowych lub oznaczanie AFP* } \\
\text { poprawia rokowanie. Uzasadnieniem dla nich } \\
\text { jest możliwość zastosowania miejscowego } \\
\text { leczenia u znacznej części chorych } \\
\text { z nawrotem. Badania te zaleca się, ponieważ } \\
\text { w nawrotach ograniczonych do wątroby } \\
\text { u znacznej części chorych można zastosować } \\
\text { miejscowe leczenie. } \\
\text { U wszystkich chorych należy oceniać } \\
\text { wydolność wątroby. } \\
\text { Chorzy po przeszczepieniu wątroby, } \\
\text { z uwagi na konieczność prowadzenia } \\
\text { immunosupresyjnego leczenia, } \\
\text { powinni być obserwowani w ośrodkach } \\
\text { transplantacyjnych }\end{array}$ \\
\hline $\begin{array}{l}\text { Rak z przewodów } \\
\text { żółciowych wewnątrz- } \\
\text { wątrobowych lub } \\
\text { pozawątrobowych }\end{array}$ & $\begin{array}{l}\text { Badanie podmiotowe } \\
\text { i przedmiotowe } \\
\text { Badania laboratoryjne i obrazowe }\end{array}$ & $\begin{array}{l}\text { Co } 6 \text { mies. w ciągu pierwszych } \\
2 \text { lat } \\
\text { Tylko ze wskazań klinicznych }\end{array}$ & $\begin{array}{l}\text { Przeprowadzanie regularnych badań } \\
\text { kontrolnych prawdopodobnie nie wpływa na } \\
\text { rokowanie }\end{array}$ \\
\hline \multirow[t]{2}{*}{ Rak okrężnicy } & $\begin{array}{l}\text { Badanie podmiotowe } \\
\text { i przedmiotowe }\end{array}$ & $\begin{array}{l}\text { Co 3-6 mies. przez } 3 \text { lata, } \\
\text { następnie co 6-12 mies. przez } \\
2 \text { lata }\end{array}$ & $\begin{array}{l}\text { TK jamy brzusznej tylko u chorych } \\
\text { zwiększonego ryzyka nawrotu (II lub wyższy } \\
\text { stopień zaawansowania, z obecnością } \\
\text { niekorzystnych czynników rokowniczych). }\end{array}$ \\
\hline & Badania laboratoryjne i obrazowe & $\begin{array}{l}\text { CEA** w surowicy } \\
\text { co 3-6 mies. przez } 3 \text { lata, } \\
\text { następnie co 6-12 mies. przez } \\
2 \text { lata; kolonoskopia w 1. roku, } \\
\text { następnie co 3-5 lat; TK jamy } \\
\text { brzusznej i klatki piersiowej } \\
\text { co 6-12 mies. przez } 3 \text { lata. } \\
\text { Inne badania - tylko ze wskazań } \\
\text { klinicznych }\end{array}$ & Kontrowersje przedstawiono w tekście \\
\hline Rak odbytnicy & $\begin{array}{l}\text { Badanie podmiotowe } \\
\text { i przedmiotowe } \\
\text { Badania laboratoryjne i obrazowe }\end{array}$ & $\begin{array}{l}\text { Jak w raku okrężnicy (lub } \\
\text { co } 6 \text { mies. przez } 2 \text { lata) } \\
\text { Kolonoskopia w } 1 \text {. roku, następnie } \\
\text { co } 5 \text { lat; rektosigmoidoskopia } \\
\text { co } 6 \text { mies. przez } 2 \text {-5 lat (u chorych } \\
\text { niepoddanych radioterapii lub } \\
\text { w przypadku obecności cechy } \\
\text { T4 lub N2); } \\
\text { CEA** - jak w raku okrężnicy } \\
\text { TK - jak w raku okrężnicy } \\
\text { oraz TK lub MR miednicy mniejszej }\end{array}$ & $\begin{array}{l}\text { Wartość intensywnej obserwacji budzi więcej } \\
\text { wątpliwości niż w przypadku raka okrężnicy }\end{array}$ \\
\hline \multirow[t]{2}{*}{ Rak kanału odbytu } & $\begin{array}{l}\text { Badanie podmiotowe } \\
\text { i przedmiotowe }\end{array}$ & $\begin{array}{l}\text { Pierwsza ocena po } 2 \text { mies. od } \\
\text { zakończenia radiochemioterapii, } \\
\text { następnie co } 3 \text { mies. przez } 3 \text { lata } \\
\text { i co } 6 \text { mies. przez kolejne } 2 \text { lata } \\
\text { (zawsze łącznie z badaniem per } \\
\text { rectum) }\end{array}$ & \\
\hline & Badania laboratoryjne i obrazowe & $\begin{array}{l}\text { U kobiet badanie cytologiczne } \\
\text { wymazu z szyjki macicy } \\
\text { co } 12 \text { mies. } \\
\text { Badania laboratoryjne i obrazowe } \\
\text { - wyłącznie ze wskazań } \\
\text { klinicznych }\end{array}$ & \\
\hline
\end{tabular}

*AFP, alfa-fetoproteina; **CEA (carcino-embryonic antygen), antygen zarodkowo-płodowy 
Tabela V. Badania kontrolne u chorych na raka piersi po radykalnym leczeniu zalecane przez Polskie Towarzystwo Onkologii Klinicznej [36]

\begin{tabular}{ll}
\hline Badanie & Częstość \\
\hline Samobadanie & Co miesiąc \\
Badanie przedmiotowe & Co 3 mies. przez pierwsze 2 lata $^{1}$ \\
& Co 6 mies. do 5 lat, następnie co 12 mies. \\
Mammografia ${ }^{2}$ & Co 12 mies.; u chorych po leczeniu oszczędzającym pierwsze badanie po 6 mies. \\
Badanie ginekologiczne & Co 12 mies. u kobiet z zachowaną macicą, leczonych tamoksyfenem³ \\
Badania obrazowe i laboratoryjne & Tylko ze wskazań klinicznych \\
Ocena stanu mineralizacji kości (densytometria) & Co 12-24 mies. \\
Ocena masy ciała & Zalecane utrzymanie wskaźnika masy ciała w przedziale 20-25 \\
\hline
\end{tabular}

${ }^{1}$ W przedinwazyjnym raku badania kontrolne co 6 miesięcy przez pierwsze 2 lata, następnie co 12 miesięcy; ${ }^{2} \mathrm{MR}$ do rozważenia u chorych nosicielek mutacji w genach BRCA; ${ }^{3}$ u chorych bez objawów ze strony narządu rodnego nie ma wskazań do wykonywania śródpochwowej USG oraz biopsji endometrium; ${ }^{4}$ dotyczy chorych o wysokim ryzyku osteoporozy związanej z leczeniem inhibitorami aromatazy lub z zahamowaniem czynności hormonalnej jajników

aktywności i odpowiedniej diety w celu zmniejszenia nadwagi), a także ocena późnych wyników leczenia. Mniejsze znaczenie ma natomiast aktywne poszukiwanie bezobjawowych przerzutów odległych, ponieważ ich wcześniejsze wykrycie w wyniku rozszerzonego zakresu badań kontrolnych nie ma istotnego wpływu na skuteczność leczenia i jakość życia chorych [30-33].

Wyniki badań wykazują, że skuteczność badań kontrolnych prowadzonych przez specjalistów dziedzin onkologicznych i przeszkolonych lekarzy rodzinnych jest porównywalna [30, 31, 34, 35]. Co prawda, nawroty raka piersi zdarzają się nawet po wielu latach, ale z upływem czasu ich ryzyko maleje, a równocześnie pojawiają się inne problemy zdrowotne, związane ze starzeniem. W tej sytuacji preferowana jest opieka sprawowana przez lekarza pierwszego kontaktu, która ma bardziej kompleksowy charakter. Rozwiązanie takie znalazło się w wielu międzynarodowych zaleceniach [30, 31, 34].

Zasady obowiązujące w obserwacji chorych po radykalnym leczeniu przedinwazyjnego raka przewodowego oraz raka inwazyjnego w stopniu I-III przedstawiono w tabeli V [36]. W ciągu pierwszych 2 lat od zakończenia leczenia zaleca się wizyty kontrolne co 3 miesiące, następnie od 2. do 5. roku co 6 miesięcy, a powyżej 5 lat - co 12 miesięcy. Schemat ten ma charakter empiryczny, bowiem nie ma badań oceniających znaczenie częstotliwości badań kontrolnych wśród ogółu chorych i w poszczególnych podgrupach raka piersi [30-33, 35, 37].

Największe znaczenie w rozpoznawaniu nawrotu choroby ma badanie przedmiotowe i podmiotowe [36]. Należy także ocenić stan psychiczny chorej i obecność objawów endokrynologicznych (uderzenia gorąca, dyspareunia, suchość pochwy, zaburzenia płciowe).

Jedynym zalecanym obrazowym badaniem w ramach kontroli po leczeniu jest rentgenowska mammografia (MMG) [30-33, 37, 38]. Wykazano, że - niezależnie od wieku chorych - wykonywana co 12 miesięcy MMG pozwala na obniżenie ryzyka zgonu z powodu raka piersi [37,
38]. U chorych poddanych leczeniu z oszczędzeniem piersi pierwszą kontrolną MMG należy wykonać po 6 miesiącach. Nie ma natomiast wskazań do rutynowego wykonywania USG i MR piersi; badania te wykonuje się jedynie w przypadku trudności w ocenie przy użyciu MMG $[39,40]$. U chorych po zabiegach rekonstrukcyjnych piersi z wykorzystaniem endoprotez MMG ma ograniczoną wartość i nie jest zalecana. W tej grupie chorych większe znaczenie w rozpoznaniu nawrotu w tkance podskórnej lub w obrębie mięśni klatki piersiowej ma badanie przedmiotowe, ew. uzupełnione MR [41].

U chorych bez podejrzanych objawów nie zaleca się wykonywania badań laboratoryjnych (morfologii krwi, biochemii), stężenia surowiczych markerów nowotworowych (CA15-3/CA27.29, CEA) oraz innych niż MMG badań obrazowych: USG jamy brzusznej, RTG klatki piersiowej, TK, MR, PET oraz scyntygrafii kości, bowiem nie wykazano wpływu tych metod na czas przeżycia chorych [30-33]. U chorych z zachowaną macicą, które otrzymują uzupełniające leczenie tamoksyfenem, istnieje zwiększone ryzyko raka endometrium, i w tej grupie co 12 miesięcy należy przeprowadzić badanie ginekologiczne [30-32,42]. Odstęp w kontrolnych badaniach ginekologicznych można wydłużyć u chorych po histerektomii i owariektomii, nie ma natomiast dowodów uzasadniających rutynowe wykonywanie śródpochwowej USG [30-32].

U chorych leczonych inhibitorami aromatazy lub metodami hamującymi czynność hormonalną jajników istnieje podwyższone ryzyko osteoporozy, i w tych grupach wskazana jest regularna ocena gęstości kości z wykorzystaniem densytometrii, a także uzupełnienie niedoborów wapnia i witaminy $D_{3}[30,31,43,44]$. W grupie podwyższonego ryzyka zdarzeń kostnych są również chore powyżej 65 r.ż. oraz młodsze z rozpoznaną osteoporozą bądź jej rodzinnym występowaniem, wskaźnikiem masy ciała $<18 \mathrm{~kg} / \mathrm{m}^{2}$, palące, nadużywające alkoholu i o małej aktywności fizycznej [45]. 
U chorych na HER2-dodatniego raka piersi po zakończonym uzupełniającym leczeniu trastuzumabem i bez objawów polekowego uszkodzenia układu krążenia nie ma potrzeby regularnego wykonywania badań echo- i elektrokardiograficznych [30-32].

$\mathrm{U}$ chorych obciążonych wywiadem rodzinnym należy rozważyć zasadność przeprowadzenia badań genetycznych w kierunku nosicielstwa mutacji $B R C A$, jeśli nie przeprowadzono ich wcześniej. Chore należy zachęcać do aktywności fizycznej (co najmniej 4 godziny ćwiczeń w tygodniu), unikania nadużywania alkoholu oraz właściwej diety w celu zachowania wskaźnika masy ciała w zakresie 20-25 [46, 47]. Ciąża po przebytym leczeniu z powodu raka piersi nie zwiększa ryzyka nawrotu. Dotychczas nie określono bezpiecznego odstępu, jaki należy zachować pomiędzy zakończeniem radykalnego leczenia a ciążą. Ciąża jest przeciwwskazana u chorych otrzymujących uzupełniające leczenie tamoksyfenem, natomiast po jej zakończeniu można wznowić hormonoterapię. W zapobieganiu ciąży zalecane jest stosowanie środków mechanicznych (prezerwatywa, wkładka domaciczna), bowiem istnieje mało danych dotyczących bezpieczeństwa stosowania hormonalnych preparatów antykoncepcyjnych po leczeniu z powodu raka piersi. Stosowanie hormonoterapii zastępczej (HTZ) zwierającej estrogen i progestagen zwiększa ryzyko nawrotu choroby i jest przeciwwskazane [48]. Rola HTZ z wykorzystaniem wyłącznie estrogenów wymaga dalszych badań [49]. U chorych z objawami dyspareunii i problemami z osiągnięciem orgazmu można rozważyć miejscowo estrogeny w postaci kremów i dopochwowych tabletek, przy czym wpływ takiego postępowania na ryzyko nawrotu jest niejasny $[50,51]$.

Brak jest zaleceń dotyczących schematu badań kontrolnych u chorych na rozsianego raka piersi. Racjonalne jest dostosowanie rodzaju wykonywanych badań do zgłaszanych dolegliwości, odchyleń od normy w badaniu przedmiotowym oraz stanu ogólnego, w celu modyfikacji dotychczasowego leczenia.

\section{Nowotwory kobiecego układu płciowego}

Dotychczas nie przeprowadzono prospektywnych badań oceniających wpływ badań kontrolnych na czas przeżycia w nowotworach kobiecego układu płciowego. Zalecenia oparte są na opiniach towarzystw naukowych, przeglądach piśmiennictwa lub opiniach ekspertów [52-55]. Jedno prospektywne badanie z losowym doborem chorych, które miało inny główny cel, w sposób istotny wpłynęło na zasady badań kontrolnych po pierwszorazowym leczeniu chorych na raka jajnika [56]. Z uwagi na specyfikę nowotworów ginekologicznych i rolę, jaką odgrywa w nim badanie ginekologiczne, które w Polsce nie jest rutynowo wykonywane przez lekarzy POZ, zasadne wydaje się prowadzenie obserwacji tych chorych przez ginekologów. Niektóre nowotwory ginekologiczne występują rzadko (rak pochwy, rak sromu, mięsaki macicy, nienabłonkowe nowotwory jajnika, choroba trofoblastyczna) i badania kontrolne w tej grupie powinny być prowadzone w specjalistycznych ośrodkach.

Badanie ginekologiczne w Polsce w ramach badań kontrolnych obejmuje wizualną ocenę krocza i sromu, ocenę pochwy i szyjki macicy we wziernikach, badanie dwuręczne przez pochwę, badanie przez odbyt oraz przezpochwowe badanie USG. W większości międzynarodowych zaleceń użycie przezpochwowego badania USG jako elementu standardowego badania ginekologicznego nie jest jednak określone [52-54, 57-59], a Society of Gynecologic Oncologists (SGO) wręcz nie zaleca jego przeprowadzania [52]. W tym świetle praktyka stosowana w Polsce wymaga środowiskowej dyskusji i ewentualnej modyfikacji. Badanie przedmiotowe powinno również objąć ocenę obwodowych węzłów chłonnych i piersi. Szczególny nacisk należy położyć na edukowanie chorych co do potencjalnych objawów wznowy, wyjaśnienie braku zasadności wykonywania badań obrazowych u chorych bez objawów i ograniczenia oznaczania surowiczych markerów.

\section{Rak błony śluzowej trzonu macicy}

W nowotworze tym nawroty występują względnie rzadko - od 2 do $15 \%$ w I stopniu do około $50 \%$ w przypadkach zaawansowanych. Około 70-100\% wznów występuje w ciągu pierwszych 3 lat $[52,60]$. U około połowy chorych objawy kliniczne są pierwszą manifestacją wznowy, a u chorych bez objawów badanie przedmiotowe pozwala wykryć 35-68\% wznów. Objawy kliniczne i/lub zmiany w badaniu przedmiotowym występują u ponad $80 \%$ chorych ze wznową. Oznacza to, że istotne jest edukowanie chorych co do objawów wznowy i konieczności regularnej kontroli po leczeniu. Obserwacja jest istotna w celu wykrywania miejscowej wznowy, jeśli istnieje możliwość jej skutecznego leczenia.

$\mathrm{U}$ chorych bez objawów nie zaleca się wykonywania badania cytologicznego, RTG klatki piersiowej i oznaczania stężenia CA125. Society of Gynecologic Oncologists nie zaleca przeprowadzania śródpochwowej USG [52]. Badania obrazowe, takie jak TK, MR czy PET-TK, mają zastosowanie w weryfikacji podejrzenia wznowy. PET-TK ma także istotne znaczenie przy kwalifikacji chorych ze wznową do leczenia operacyjnego [52,61].

Zasady prowadzenia badań kontrolnych po leczeniu raka błony śluzowej trzonu macicy przedstawiono w tabeli Vl.

\section{Rak jajnika, rak jajowodu i pierwotny rak otrzewnej}

U około 75\% chorych na raka jajnika dochodzi do nawrotu po pierwszorazowym leczeniu. Mediana czasu wystąpienia nawrotu w stopniu IIB-IV wynosi około 22 miesięcy [52]. Najczęściej pierwszym objawem wznowy (37\% chorych) jest wzrost stężenia CA125, który poprzedza kliniczne ob- 
Tabela VI. Zalecane badania kontrolne u chorych na raka błony śluzowej trzonu macicy

\begin{tabular}{lll}
\hline Kategoria chorych & Rodzaj badania* & Częstość wykonywanych badań \\
\hline $\begin{array}{l}\text { Stopień FIGO** IA G1/G2 } \\
\text { (typ endometrioidalny) }\end{array}$ & $\begin{array}{l}\text { Podmiotowe i przedmiotowe z badaniem } \\
\text { ginekologicznym, badaniem per rectum, } \\
\text { do rozważenia przezpochwowe USG }\end{array}$ & Co 6 mies. w pierwszym roku, następnie \\
& jw. 12 mies. \\
$\begin{array}{l}\text { Stopień FIGO** IA G3, IB-II } \\
\text { (typ endometrioidalny) }\end{array}$ & jw. & Co 3 mies. w pierwszym roku, co 6 mies. \\
$\begin{array}{l}\text { Stopień FIGO** III-IV oraz wszystkie stopnie } \\
\text { W przypadku typów innych } \\
\text { niż raki endometrialne }\end{array}$ & & do 5 lat, następnie co 12 mies. \\
\hline
\end{tabular}

*We wszystkich stopniach zaawansowania badania obrazowe jedynie w sytuacji wskazań klinicznych **FIGO, International Federation of Gynecology and Obstetrics

jawy choroby średnio o 5 miesięcy. U 15\% chorych wznowa manifestuje się wystąpieniem objawów klinicznych, a u 4\% — objawami klinicznymi i wzrostem stężenia CA125 [56, 62]. Wyniki dużego badania klinicznego z randomizacją wykazały, że rozpoczęcie chemioterapii jedynie na podstawie wzrostu stężenia CA125 nie wpływa na czas przeżycia [56]. W tej sytuacji należy rozważyć i przedyskutować z chorą celowość oznaczania stężenia tego markera.

Badania obrazowe (TK, MR, PET-TK) mają zastosowanie w weryfikacji podejrzenia wznowy i w kwalifikacji do leczenia operacyjnego z powodu nawrotu [52]. Nie ma wskazań do ich rutynowego wykonywania u chorych bez objawów nawrotu.

W guzach jajnika o granicznej złośliwości nawroty występują u około $8 \%$ chorych, przy czym około 30\% nawrotów ma charakter złośliwy [63]. Wznowy występują często wiele lat po zakończeniu pierwszorazowego leczenia: 70\% po 5 latach, a 30\% po 10 latach [52]. Ryzyko wznowy jest większe w przypadku zabiegów oszczędzających [63].W tej grupie istotne jest okresowe wykonywanie badań USG za pomocą sondy dopochwowej, co pozwala zidentyfikować wcześnie zmianę w pozostawionym jajniku i przeprowadzić zabieg $[64,65]$. Badania obrazowe (TK, MR, PET-TK) mają zastosowanie wyłącznie w weryfikacji podejrzenia wznowy.

Zasady badań kontrolnych po leczeniu z powodu raka jajnika przedstawiono w tabeli VII. Dotyczą one również raka jajowodu i pierwotnego raka otrzewnej.

\section{Nienabłonkowe nowotwory jajnika i guzy ze sznurów płciowych}

U dużej części chorych na nienabłonkowe nowotwory jajnika możliwe jest pierwotne leczenie oszczędzające z zachowaniem macicy i drugiego jajnika. Z uwagi na skąpe dane $z$ piśmiennictwa zalecenia w tej grupie oparte są jedynie na opiniach ekspertów $[52,55]$. Konieczna jest wieloletnia obserwacja, ponieważ połowa wznów występuje po 5 latach od zakończeniu leczenia, w tym około połowa - w miednicy. U chorych na nowotwory ze sznurów płciowych wznowy występują nawet po 20 latach od zakończeniu leczenia [66]. Część chorych może otrzymać skuteczną chemioterapię drugiej linii [67].

\section{Rak szyjki macicy}

Około 3/4 wznów raka szyjki macicy występuje w ciągu pierwszych 24-36 miesięcy po zakończeniu leczenia [68]. Typowymi objawami podmiotowymi wznowy są: ból brzucha lub ból w okolicy miednicy mniejszej, krwawienie z pochwy, ból lub obrzęk limfatyczny kończyn dolnych, objawy ze strony układu moczowego, kaszel i ubytek masy ciała. Tylko 26-36\% nowotworów wykrywa się w trakcie badań kontrolnych. Badanie fizykalne, które powinno obejmować również badanie przez pochwę i odbyt, pozwala wykryć 29-75\% bezobjawowych klinicznie nawrotów [69]. Badanie cytologiczne pozwala wykryć głównie nowe zmiany w obrębie pochwy i powinno być wykonywane raz w roku (tab. VIII). W przypadku zmian stwierdzanych w badaniu cytologicznym konieczne jest wykonanie kolposkopii z pobraniem wycinków [68, 69]. Wyniki badań retrospektywnych wskazują jednak, że tylko niewielką część wznów (0-17\%) rozpoznaje się dzięki tej metodzie. Badanie cytologiczne ma ograniczoną przydatność po radioterapii [69].

Nie zaleca się wykonywania corocznego badania RTG klatki piersiowej $[52,54,57,69]$. To i inne badania obrazowe (RTG, TK, MR, PET-TK) są wskazane u chorych z podmiotowymi objawami lub nieprawidłowościami w badaniu fizykalnym [70]. Wartość przezpochwowego badania USG jest wątpliwa. Nie zaleca się oznaczania stężenia antygenu SCC (squamous cell carcinoma antigen). Ponieważ prawie $40 \%$ chorych zgłasza się na nieplanowane wizyty kontrolne z powodu objawów podmiotowych lub klinicznego podejrzenia wznowy, istotna jest ich edukacja w zakresie objawów wznowy [68]. Chore, u których wykonano trachelektomię (zabieg z zachowaniem macicy), wymagają badań kontrolnych w ośrodku, w którym przeprowadzono leczenie.

\section{Rak sromu}

Do wznowy najczęściej dochodzi w ciągu pierwszych 2 lat po leczeniu - częściej u chorych z przerzutami do węzłów chłonnych. Po 24 miesiącach od zakończenia leczenia ryzyko wznowy jest takie samo u chorych z zajętymi i niezajętymi węzłami chłonnymi, jednak utrzymuje się przez wiele lat (wznowy po 5 latach występują u 35\% chorych) [71]. U ponad 90\% chorych, u których doszło do późnej 
Tabela VII. Zalecane badania kontrolne u chorych na nowotwory jajnika i jajowodu oraz pierwotnego raka otrzewnej

\begin{tabular}{|c|c|c|}
\hline Kategoria chorych & Rodzaj badania & Częstość wykonywanych badań \\
\hline \multicolumn{3}{|l|}{ Nabłonkowe nowotwory jajnika i jajowodu } \\
\hline \multirow[t]{4}{*}{ Stopień FIGO* I-IV } & $\begin{array}{l}\text { Podmiotowe i przedmiotowe } z \text { badaniem } \\
\text { ginekologicznym, badaniem per rectum oraz } \\
\text { przezpochwowym USG }\end{array}$ & $\begin{array}{l}\text { Co } 3 \text { mies. w pierwszych } 2 \text { latach; co } \\
\text { 3-6 mies. w 3. roku, co } 6 \text { mies. do } 5 \text { lat, } \\
\text { następnie co } 12 \text { mies. }\end{array}$ \\
\hline & Antygen CA125 & Po dyskusji z chorą, razem z badaniem \\
\hline & Badania obrazowe & Jedynie w sytuacji wskazań klinicznych \\
\hline & $\begin{array}{l}\text { Zalecana konsultacja genetyczna, jeżeli } \\
\text { nie została wcześniej przeprowadzona }\end{array}$ & $\begin{array}{l}\text { W chwili rozpoczynania obserwacji lub } \\
\text { powtórnie w momencie wystąpienia nowego } \\
\text { zachorowania w rodzinie }\end{array}$ \\
\hline \multicolumn{3}{|l|}{ Guzy jajnika o niskiej złośliwości } \\
\hline Stopień FIGO* I-IV & $\begin{array}{l}\text { Zakres badań jak w nowotworach } \\
\text { nabłonkowych }\end{array}$ & Co 6 mies. do 5 lat, następnie co 12 mies. \\
\hline $\begin{array}{l}\text { Stopień FIGO* I z zachowaniem narządu } \\
\text { rodnego: } \\
\text { - po usunięciu guza } \\
\text { - po usunięciu przydatka }\end{array}$ & $\begin{array}{l}\text { Zakres badań jak w nowotworach } \\
\text { nabłonkowych; rozważyć usunięcie macicy } \\
\text { i drugiego przydatka po zakończeniu rozrodu }\end{array}$ & Jak wyżej \\
\hline \multicolumn{3}{|c|}{ Guzy jajnika wywodzące się z komórek rozrodczych } \\
\hline $\begin{array}{l}\text { I. Rozrodczak (dysgerminoma) } \\
\text { II. Nie-rozrodczak: }\end{array}$ & $\begin{array}{l}\text { Zakres badań jak w nowotworach } \\
\text { nabłonkowych jajnika }\end{array}$ & $\begin{array}{l}\text { Co } 3 \text { mies. w pierwszych } 2 \text { latach, następnie } \\
\text { co } 12 \text { mies. }\end{array}$ \\
\hline $\begin{array}{l}\text { 1. guz pęcherzyka żółtkowego (endodermal } \\
\text { sinus tumor/yolk sac tumor) } \\
\text { 2. potworniak niedojrzały (teratoma } \\
\text { immaturum/malignum) } \\
\text { 3. rak zarodkowy (carcinoma embryonale) } \\
\text { 4. kosmówczak zarodkowy (non-gestational } \\
\text { chorioncarcinoma) } \\
\text { III. Mieszany guz złośliwy germinalny } \\
\text { (tumor mixtus mesodermalis malignus) }\end{array}$ & $\begin{array}{l}\text { Stężenie AFP** }{ }^{*} \mathrm{HCG}^{* * *}, \mathrm{LDH}^{* * * *} \\
\text { Badania obrazowe }\end{array}$ & $\begin{array}{l}\text { Do } 2 \text { lat po wraz z badaniem przedmiotowym } \\
\text { Jedynie według wskazań klinicznych i wzrostu } \\
\text { stężenia markerów, ew. częściej w ciągu } \\
\text { pierwszych } 2 \text { lat w przypadku prawidłowych } \\
\text { stężeń markerów w trakcie pierwotnego } \\
\text { leczenia }\end{array}$ \\
\hline \multicolumn{3}{|l|}{ Guzy ze sznurów płciowych } \\
\hline $\begin{array}{l}\text { I. Grupa guzów z komórek ziarnistych } \\
\text { i podścieliska } \\
\text { A. Ziarniszczak (folliculoma, granulosa cell } \\
\text { tumor) } \\
\text { B. Guzy z grupy otoczkowiak-włókniak } \\
\text { (thecoma-fibroma) } \\
\text { Il. Grupa guzów z komórek Sertoliego } \\
\text { i podścieliska } \\
\text { 1. Guz z komórek Sertoliego } \\
\text { 2. Guz z komórek Leydiga } \\
\text { III. Guzy z komórek Sertoliego i Leydiga III. } \\
\text { Gynandroblastoma } \\
\text { IV. Guzy pochodzące ze sznurów płciowych } \\
\text { i zrębu z obrączkowatymi cewkami (SCTAT } \\
\text { - sex cord tumor with annular tubules) }\end{array}$ & $\begin{array}{l}\text { Jak w nowotworach nabłonkowych } \\
\text { Badania obrazowe }\end{array}$ & $\begin{array}{l}\text { Co } 3 \text { mies. w pierwszych } 2 \text { latach, co } 6 \text { mies. } \\
\text { po } 2 \text { latach } \\
\text { Jedynie w sytuacji wskazań klinicznych }\end{array}$ \\
\hline
\end{tabular}

Tabela VIII. Zalecane badania kontrolne u chorych na raka szyjki macicy

\begin{tabular}{|c|c|c|}
\hline Kategoria chorych & Rodzaj badania & Częstość wykonywanych badań \\
\hline \multirow[t]{3}{*}{$\begin{array}{l}\text { Niskie ryzyko wznowy: IA, chore leczone } \\
\text { wyłącznie chirurgicznie bez leczenia } \\
\text { uzupełniającego }\end{array}$} & $\begin{array}{l}\text { Podmiotowe i przedmiotowe wraz z badaniem } \\
\text { ginekologicznym i badaniem per rectum }\end{array}$ & $\begin{array}{l}\text { Co } 6 \text { mies. w pierwszych } 2 \text { latach, co } \\
12 \text { mies. do } 5 \text { lat, po } 5 \text { latach powrót do badań } \\
\text { obejmujących populację ogólną }\end{array}$ \\
\hline & Badanie cytologiczne & Co 12 mies. \\
\hline & Badania obrazowe & Jedynie w sytuacji wskazań klinicznych \\
\hline \multirow{3}{*}{$\begin{array}{l}\text { Podwyższone ryzyko wznowy: chore leczone } \\
\text { pierwotnie chirurgicznie z leczeniem } \\
\text { uzupełniającym lub poddane radio(chemio)- } \\
\text { terapii }\end{array}$} & $\begin{array}{l}\text { Podmiotowe i przedmiotowe wraz z badaniem } \\
\text { ginekologicznym i badaniem per rectum }\end{array}$ & $\begin{array}{l}\text { Co } 3 \text { mies. w pierwszych } 2 \text { latach, co } \\
12 \text { mies. do } 5 \text { lat, po } 5 \text { latach powrót do badań } \\
\text { obejmujących populację ogólną }\end{array}$ \\
\hline & Badanie cytologiczne & Co 12 mies. \\
\hline & Badania obrazowe & Jedynie w sytuacji wskazań klinicznych \\
\hline
\end{tabular}


Tabela IX. Zalecane badania kontrolne u chorych na raka sromu i raka pochwy

\begin{tabular}{lll}
\hline Kategoria chorych & Rodzaj badania & Częstość wykonywanych badań \\
\hline Stopień I-IV & $\begin{array}{l}\text { Podmiotowe i przedmiotowe, z badaniem } \\
\text { ginekologicznym i badaniem per rectum; u chorych } \\
\text { na raka sromu szczególnie uważna ocena } \\
\text { makroskopowa sromu, krocza oraz badanie } \\
\text { pachwin (ewentualnie wulwoskopia) }\end{array}$ & $\begin{array}{l}\text { Co } 3 \text { mies. w pierwszych } 2 \text { latach, co } 6 \text { mies. } \\
\text { do } 5 \text { lat, następnie co 12 mies. }\end{array}$ \\
& $\begin{array}{l}\text { Badanie cytologiczne (przy zachowanej macicy) } \\
\text { Badanie radiologiczne }\end{array}$ & $\begin{array}{l}\text { Co 12 mies. } \\
\text { Jedynie w sytuacji wskazań klinicznych }\end{array}$ \\
\hline
\end{tabular}

wznowy, ma ona charakter miejscowy [72]. Z uwagi na rolę wirusów HPV (human papilloma virus) w raku sromu istotna jest diagnostyka w kierunku raka szyjki macicy, pochwy oraz okolicy odbytu. Nie udowodniono wartości klinicznej i nie zaleca się wykonywania dodatkowych badań obrazowych (tab. IX). Wartość przezpochwowego badania USG jest wątpliwa. W razie występowania objawów podmiotowych lub cech wskazujących na obecność przerzutów należy wykonać badania obrazowe i postępować jak w przypadku raka szyjki macicy [52].

\section{Rak pochwy}

Rak pochwy jest względnie rzadkim nowotworem, a dane na temat obserwacji po leczeniu są skąpe. Nie wykazano korzyści wynikających z rutynowego wykonywania badań cytologicznych lub obrazowych u kobiet niezgłaszających objawów podmiotowych (tab. IX) [52]. W piśmiennictwie nie ma danych dotyczących wartości śródpochwowej USG.

\section{Nowotwory układu moczowo-płciowego Rak gruczołu krokowego (RGK)}

Rutynowa kontrola po radykalnym leczeniu powinna obejmować wywiad i ocenę stężenia swoistego antygenu sterczowego (PSA - prostate-specific antygen) oraz, w razie potrzeby, badanie per rectum. Wywiad powinien uwzględniać aspekty psychologiczne, potencjalne objawy sugerujące nawrót choroby lub późne powikłania po leczeniu. Wymienione badania powinny być wykonywane co 3 miesiące przez pierwszy rok, w dwóch kolejnych latach co 6 miesięcy, a następnie co rok. Wykonywanie badań obrazowych u chorych bez objawów lub cech wznowy biochemicznej jest nieuzasadnione. Jednorazowe stwierdzenie wzrostu stężenia PSA powinno być zweryfikowane powtórnym badaniem przed podjęciem decyzji o pogłębianiu diagnostyki w celu poszukiwania wznowy. Nadal trwa dyskusja dotycząca definicji progresji biochemicznej. Jeśli najniższe stężenie PSA po radykalnej prostatektomii nie przekracza $0,01 \mathrm{ng} / \mathrm{ml}$, ryzyko nawrotu wynosi około 4\% [73]. Jednak około 2/3 chorych, u których stężenie PSA przekracza 0,05 ng/ml, przeżywa 5 lat bez nawrotu biochemicznego [74]. Definicja nawrotu biochemicznego po radioterapii według ustaleń RTOG-ASTRO
(Radiation Therapy Oncology Group - American Society for Radiation Oncology) z 2006 roku to wzrost stężenia PSA o $2 \mathrm{ng} / \mathrm{ml}$ powyżej osiągniętego najniższego stężenia [75].

Stężenie PSA po skutecznym zabiegu operacyjnym powinno się stać nieoznaczalne w ciągu 6 tygodni [76]. Utrzymujące się wykrywalne stężenie PSA świadczy o istnieniu aktywnej choroby (mikroprzerzuty, choroba resztkowa w miednicy). Gwałtownie wzrastające stężenie PSA świadczy raczej o rozsiewie, podczas gdy późny i powolny wzrost stężenia PSA cechuje nawroty miejscowe [77]. W porównaniu z radykalną prostatektomią, po radioterapii obniżenie stężenia PSA do najniższego poziomu następuje dużo wolniej i czasami przekracza nawet 3 lata. Obniżenie stężenia PSA poniżej 0,05 ng/ml związane jest z dobrym rokowaniem [78]. Czas podwojenia stężenia PSA (PSADT — PSA doubling time) zależy od lokalizacji nawrotu — PSADT wynoszący kilkanaście miesięcy sugeruje raczej nawrót miejscowy, natomiast kilka — rozsiew choroby [79].

Badanie per rectum jest uzasadnione szczególnie u chorych z niezróżnicowanymi nowotworami lub w nowotworach niewywodzących się z tkanki gruczołowej stercza (np. mięsaki) [80]. W takich przypadkach nie dochodzi do wzrostu stężenia PSA w trakcie progresji i badanie per rectum może być jedyną metodą rozpoznania bezobjawowej wznowy miejscowej.

U chorych po radioterapii, u których występują objawy ze strony dolnego odcinka przewodu pokarmowego, należy przeprowadzić pełną diagnostykę endoskopową w celu ustalenia ich przyczyny (enteropatia po napromienianiu, przewlekłe procesy zapalne, zmiany nowotworowe w obrębie jelita grubego). Zalecenia dotyczące obserwacji chorych na RGK po radykalnym leczeniu przedstawiono $w$ tabeli X.

\section{Rak nerki}

Nie wykazano, aby jakikolwiek schemat obserwacji po radykalnym leczeniu operacyjnym wczesnego raka nerki wpływał na poprawę rokowania. Zasady obserwacji chorych po radykalnym leczeniu raka nerki opracowane przez Europejskie Towarzystwo Urologiczne (EAU - European Association of Urology) zawarte są w tabeli XI. Wytyczne te uwzględniają ryzyko nawrotu określone za pomocą zwalidowanych nomogramów, uwzględniających m.in. stopnie 
Tabela X. Zalecane badania kontrolne u chorych na raka gruczołu krokowego po radykalnym leczeniu

\begin{tabular}{lll}
\hline Badanie & Częstotliwość & Uwagi \\
\hline $\begin{array}{l}\text { Badanie podmiotowe, } \\
\text { stężenie *PSA }\end{array}$ & $\begin{array}{l}\text { Po } 3 \text { mies. od zakończenia leczenia, co 6 mies. przez } \\
\text { Blata, następnie co 12 mies. }\end{array}$ \\
Badanie per rectum & jw. & $\begin{array}{l}\text { Szczególnie uzasadnione u chorych z niezróżnicowanymi } \\
\text { nowotworami lub w przypadku nowotworów } \\
\text { niewywodzących się z tkanki gruczołowej stercza } \\
\text { (np. mięsaki), które nie wydzielają PSA }\end{array}$ \\
\hline
\end{tabular}

*PSA (prostate-specific antygen), swoisty antygen sterczowy

Tabela XI. Zalecane badania kontrolne u chorych na raka nerki po radykalnym leczeniu*

\begin{tabular}{lccccccc}
\hline Ryzyko nawrotu** & 6. mies. & 1. rok & 2. rok & 3. rok & 4. rok & 5. rok & Po 5 latach*** \\
\hline Niskie & USG & TK & USG & TK & USG & TK \\
Średnie & TK & TK & TK & USG & TK & TK \\
Wysokie & TK & TK & TK & TK & TK & TK co 2 lata \\
\hline
\end{tabular}

*TK we wszystkich przypadkach z objęciem klatki piersiowej i jamy brzusznej; **oparte na nomogramach uwzględniających stopnie T, N i M, obecność objawów w momencie rozpoznania, zróżnicowanie nowotworu i średnicę guza [81-84]; *** tylko w przypadkach uzasadnionych klinicznie i na podstawie indywidualnej oceny ryzyka

T, N i M, obecność objawów w momencie rozpoznania, zróżnicowanie nowotworu i średnicę guza [81-84].

\section{Rak pęcherza moczowego}

Ryzyko nawrotu choroby u chorych poddanych radykalnemu wycięciu pęcherza zależy ściśle od stopnia zaawansowania patologicznego raka i zwiększa się od 5\% w przypadku chorych z guzami pT1G3 do niemal 100\% u chorych z pN2. Ryzyko nawrotu jest największe w okresie pierwszych 24 miesięcy po cystektomii, maleje pomiędzy 24. a 36. miesiącem i jest względnie małe po upływie 36 miesięcy.

Wykonanie cystoskopii po 3 miesiącach jest uzasadnione u wszystkich chorych poddanych przezcewkowej elektroresekcji guza pęcherza moczowego (transurethral resection of bladder tumor - TURbt) z powodu nieinwazyjnego raka. W przypadku guzów T1 G2/G3 sugeruje się przeprowadzenie w ciągu 3 miesięcy powtórnej elektroresekcji miejsc, w których wcześniej wykonano TURbt - utkanie raka stwierdza się u ponad 1/3 z tych chorych. W przypadku guzów małego ryzyka (pojedynczy guz, Ta G1, średnica $<3 \mathrm{~cm}$ ), bez nawrotu w ciągu 3 miesięcy od pierwszej TURbt, kontrolną cystoskopię można opóźnić do 9. miesiąca, a następnie wykonywać to badanie co 12 miesięcy. U chorych z wysokim ryzykiem nawrotu cystoskopię wykonuje się co 3 miesiące w ciągu pierwszych 2 lat, co 4 miesiące w 3. roku obserwacji, co 6 miesięcy w latach 4. i 5 ., a następnie co rok. Określenie standardowego postępowania w przypadku guzów średniego ryzyka jest trudne ze względu na dużą zmienność czynników prognostycznych. Jeżeli wystąpi wznowa, schemat kontrolnych badań cystoskopowych wdraża się na nowo. U chorych z pojedynczym guzem Ta/G1, u których w ciągu 5 lat nie doszło do nawrotu, można odstąpić od kontrolnych cystoskopii. U pozostałych chorych wskazane jest wykonywanie kontrolnej cystoskopii co rok przez 10 lat, a u chorych z guzami dużego ryzyka — przez całe życie. Wizyty kontrolne, obejmujące także USG nerek i zbiornika jelitowego oraz oznaczenie stężenia kreatyniny i elektrolitów we krwi, przeprowadza się co 3 miesiące w ciągu pierwszych 2 lat, a później co 6 miesięcy do 5 lat po cystektomii. Chorzy leczeni napromienianiem z zachowaniem pęcherza moczowego wymagają wykonywania kontrolnych cystoskopii co 3 miesiące przez pierwsze 2 lata obserwacji, a następnie co 6 miesięcy [85]. Zalecenia dotyczące obserwacji chorych po radykalnym leczeniu raka pęcherza moczowego przedstawiono w tabeli XII.

\section{Nowotwory jądra}

Nie ma ogólnie przyjętego schematu dotyczącego rytmu i zakresu badań kontrolnych u chorych leczonych z powodu nowotworów jądra. Wczesne wykrycie i leczenie nawrotu są podstawowym celem regularnie wykonywanych badań kontrolnych w ciągu 5-10 lat od rozpoznania. W ostatnim czasie pojawia się coraz więcej sugestii, aby w ramach badań kontrolnych wykorzystywać MR zamiast TK z uwagi na mniejsze ryzyko związane z toksycznością kontrastu i uniknięcie potencjalnie szkodliwego działania promieniowania jonizującego. W tabeli XIII przedstawiono wytyczne EAU z 2011 roku [86].

\section{Rak prącia}

W zlokalizowanych rakach prącia przeżycia 5-letnie wynoszą około $85 \%$, a u chorych z przerzutami do regionalnych węzłów chłonnych lub okolicznych tkanek - 59\%. W przypadku uogólnionej choroby jedynie 11\% chorych przeżywa 5 lat. Pojawiają się doniesienia, że raki prącia związane z zakażeniem HPV charakteryzują 
Tabela XII. Zalecane badania kontrolne u chorych na raka pęcherza moczowego po radykalnym leczeniu

\begin{tabular}{|c|c|c|c|c|c|c|c|}
\hline \multirow{2}{*}{$\begin{array}{l}\text { Kategoria } \\
\text { chorych }\end{array}$} & \multicolumn{2}{|c|}{$\begin{array}{l}\text { Badanie cytologiczne moczu } \\
\text { i cystoskopia }\end{array}$} & \multicolumn{2}{|c|}{$\begin{array}{l}\text { TK jamy brzusznej i miednicy, } \\
\text { RTG klatki piersiowej }\end{array}$} & \multicolumn{2}{|c|}{$\begin{array}{l}\text { Ocena czynności } \\
\text { wątroby i nerek }\end{array}$} & \multirow{2}{*}{$\begin{array}{c}\text { Losowe } \\
\text { biopsje ściany } \\
\text { pęcherza }\end{array}$} \\
\hline & $\begin{array}{l}\text { Co 3-6 mies. } \\
\text { przez } 2 \text { lata }\end{array}$ & $\begin{array}{c}\text { Co 6-12 mies. } \\
\text { w kolejnych } \\
\text { latach }\end{array}$ & - & - & - & - & \\
\hline $\begin{array}{l}\text { Rak naciekający } \\
\text { (radykalna } \\
\text { cystektomia) }\end{array}$ & $\begin{array}{l}\text { Co 3-6 mies. } \\
\text { przez } 2 \text { lata* }\end{array}$ & $\begin{array}{c}\text { Co 6-12 mies. } \\
\text { w kolejnych } \\
\text { latach* }\end{array}$ & $\begin{array}{l}\text { Co 3-6 mies. } \\
\text { przez } 2 \text { lata }\end{array}$ & $\begin{array}{c}\text { Co 6-12 mies. } \\
\text { w kolejnych } \\
\text { latach }\end{array}$ & $\begin{array}{l}\text { Co 3-6 mies. } \\
\text { przez } 2 \text { lata }\end{array}$ & $\begin{array}{c}\text { W przypadku } \\
\text { wskazań } \\
\text { w kolejnych } \\
\text { latach }\end{array}$ & - \\
\hline $\begin{array}{l}\text { Rak naciekający } \\
\text { (leczenie } \\
\text { z zachowaniem } \\
\text { pęcherza) }\end{array}$ & $\begin{array}{l}\text { Co 3-6 mies. } \\
\text { przez } 2 \text { lata }\end{array}$ & $\begin{array}{c}\text { Co 6-12 mies. } \\
\text { w kolejnych } \\
\text { latach }\end{array}$ & $\begin{array}{l}\text { Co 3-6 mies. } \\
\text { przez } 2 \text { lata }\end{array}$ & $\begin{array}{c}\text { Co 6-12 mies. } \\
\text { w kolejnych } \\
\text { latach }\end{array}$ & $\begin{array}{l}\text { Co 3-6 mies. } \\
\text { przez } 2 \text { lata }\end{array}$ & $\begin{array}{c}\text { W przypadku } \\
\text { wskazań } \\
\text { w kolejnych } \\
\text { latach }\end{array}$ & $\begin{array}{l}\text { Co 3-6 mies. } \\
\text { przez } 2 \text { lata }\end{array}$ \\
\hline
\end{tabular}

*tylko badanie cytologiczne

Tabela XIII. Wytyczne European Association of Urology dotyczące obserwacji chorych na złośliwe nowotwory jądra po radykalnym leczeniu [86]*

\begin{tabular}{ll}
\hline Badanie & Częstotliwość \\
\hline $\begin{array}{l}\text { Badanie przedmiotowe, markery nowotworowe — alfa-fetoproteina } \\
\text { (AFP), beta-gonadotropina kosmówkowa (B-hCG) i dehydrogenaza }\end{array}$ & $\begin{array}{l}\text { Co } 3 \text { mies. przez pierwsze 2 lata, co 6 mies. przez kolejne } 3 \text { lata, } \\
\text { nleczanownie co } 12 \text { mies. }\end{array}$ \\
TK j. brzusznej i miednicy & \\
TK klatki piersiowej & Co 6 mies. przez pierwsze 2 lata, następnie według wskazań \\
TK głowy & Według wskazań \\
\hline
\end{tabular}

*Według wytycznych ESMO u każdego chorego na nowotwory jądra w 2. i 5. roku obserwacji należy także wykonać badania biochemiczne surowicy, oceniające odległe działania niepożądane leczenia (stężenie mocznika, kreatyniny, trójglicerydów, glukozy LH, FSH, testosteronu oraz frakcji cholesterolu)

się lepszym rokowaniem, jednak dane te wymagają potwierdzenia. W tabeli XIV przedstawiono wytyczne EAU dotyczące obserwacji po radykalnym leczeniu z powodu raka prącia [87].

\section{Czerniaki}

Dotychczas nie opracowano opartych na dowodach z badań klinicznych uniwersalnych zaleceń prowadzenia badań kontrolnych po radykalnym leczeniu czerniaków skóry [88-92]. Zalecenia te oparte są na danych empirycznych związanych z czasem i rodzajem występowania ewentualnych nawrotów choroby [92-97]. Częstotliwość i rodzaj badań oraz czas prowadzenia obserwacji należy uzależnić od indywidualnego ryzyka nawrotu choroby (głównie jej wyjściowego zaawansowania) [92, 93, 95, 96, 98-102]. Ryzyko nawrotu u chorych w stopniu T1-T2 N0 jest względnie małe, natomiast w stopniach IIIA, IIIB i IIIC 5-letnie przeżycia wolne od nawrotu choroby wynoszą odpowiednio: 50-63\%, 26-32\% i 11-12\% [93, 102, 103].

Największe prawdopodobieństwo nawrotu czerniaka występuje w ciągu pierwszych 2-3 lat po leczeniu. Schematy badań kontrolnych w tym okresie powinny być bardziej intensywne, co zwiększa szansę wykrycia miejscowo-regionalnego nawrotu kwalifikującego się do radykalnego leczenia chirurgicznego [88, 96, 99, 100, 103-105]. Około
20-28\% pierwszych nawrotów czerniaka stanowi wznowa miejscowa lub przerzuty in-transit, ponad $25 \%$ - przerzuty do regionalnych węzłów chłonnych (odsetek ten zmniejszył się po wprowadzeniu biopsji węzła wartowniczego), a 15-50\% — odległe przerzuty. Ponieważ dużą część (nawet powyżej 60\%) nawrotów miejscowo-regionalnych mogą wykryć sami chorzy, należy ich poinformować o konieczności samokontroli operowanej okolicy pierwotnego guza oraz regionalnego spływu chłonnego. Po upływie 5 lat od pierwotnego leczenia czerniaka do nawrotu dochodzi u mniej niż 5\% chorych $[96,105]$. Mogą one jednak występować nawet po wielu latach i dotyczy to w jednakowych proporcjach nawrotów miejscowo-regionalnych i odległych.

Badania kontrolne przeprowadza się rutynowo co 3 miesiące w ciągu pierwszych 2 lat od leczenia, co 6 miesięcy przez następne 3 lata - i później co rok. Chorzy na czerniaka in situ nie wymagają wieloletnich obserwacji, z wyjątkiem chorych z mnogimi atypowymi znamionami skóry lub innymi czynnikami zwiększonego ryzyka zachorowania. Częstość badań kontrolnych powinna być również mniejsza u chorych na czerniaki w stopniu IA (co 6-12 miesięcy); w tej grupie nie ma wskazań do wykonywania żadnych dodatkowych badań $[89,93,106]$. Ponieważ nie opracowano opartych na badaniach klinicznych schematów badań kontrolnych po leczeniu czerniaków, istotne jest również 
Tabela XIV. Wytyczne European Association of Urology dotyczące obserwacji chorych na raka prącia po radykalnym leczeniu [87] (minimalny czas obserwacji: 5 lat)

\begin{tabular}{|c|c|c|}
\hline Sytuacja kliniczna & & Częstotliwość \\
\hline \multirow[t]{2}{*}{ Zabieg oszczędzający } & Badanie przedmiotowe & Co 3 mies. przez 2 lata, następnie co 6 mies. \\
\hline & $\begin{array}{l}\text { Powtórna biopsja po laseroterapii, krioterapii } \\
\text { i terapii fotodynamicznej }\end{array}$ & \\
\hline Zabieg radykalny & Badanie przedmiotowe & Co 3 mies. przez 2 lata, następnie co 12 mies. \\
\hline \multicolumn{3}{|c|}{ Obserwacja węzłów chłonnych } \\
\hline $\mathrm{pN}-$ & Badanie przedmiotowe & Co 3 mies. przez 2 lata, następnie co 12 mies. \\
\hline \multirow[t]{2}{*}{$\begin{array}{l}\text { pN+i chorzy niepoddani } \\
\text { limfadenektomii }\end{array}$} & $\begin{array}{l}\text { Badanie przedmiotowe, USG węzłów chłonnych, } \\
\text { w razie podejrzenia wznowy celowana biopsja } \\
\text { cienkoigłowa }\end{array}$ & Co 3 mies. przez 2 lata, następnie co 6 mies. \\
\hline & TK, MR & Według wskazań \\
\hline
\end{tabular}

uwzględnienie indywidualnych preferencji pacjenta. Wydaje się, że we wczesnych stopniach zaawansowania mniej intensywne badania kontrolne nie mają negatywnego wpływu na czas przeżycia [96, 106-108].

Pacjenci po leczeniu czerniaka skóry mają zwiększone ryzyko zachorowania na kolejnego czerniaka, dlatego obowiązkowe są badania lekarskie całej skóry (z zastosowaniem dermatoskopii). Ryzyko rozwoju drugiego pierwotnego czerniaka u chorych po leczeniu czerniaka szacuje się nawet na $10 \%$ w ciągu całego życia. W przypadku zespołu atypowych znamion można wykorzystywać technikę powtarzanych zdjęć fotograficznych całej skóry lub regularną ocenę wideodermatoskopową. Chorzy na czerniaki są również narażeni na zwiększone ryzyko rozwoju innych nowotworów złośliwych skóry. Powinni być oni również poinformowani, że ich krewni mają większe ryzyko zachorowania na czerniaka, nie ma jednak wskazań do badań genetycznych.

Najważniejszym elementem obserwacji pod kątem nawrotu miejscowo-regionalnego po leczeniu jest ocena blizny po wycięciu ogniska pierwotnego oraz regionalnych węzłów chłonnych i spływu chłonnego (rozsiew in-transit). Do badania regionalnych węzłów chłonnych, oprócz badania palpacyjnego, można stosować USG, która charakteryzuje się wysoką czułością i swoistością (zwłaszcza w grupie chorych, u których nie wykonano biopsji węzła wartowniczego) [109, 110].

Kontrolne testy krwi i badania obrazowe często nie przynoszą oczekiwanych wyników, ponieważ aż $68 \%$ nawrotów wykrywa się na podstawie objawów klinicznych, 26\% na podstawie badania przedmiotowego (często samobadania), a jedynie 6\% dzięki zdjęciu RTG klatki piersiowej [91]. Swoistość RTG klatki piersiowej dla wykrywania przerzutów czerniaka do płuc wynosi jedynie około 50\%, i badanie to ma niewielkie zastosowanie u chorych w wyjściowych stopniach zaawansowania I-II i bez objawów klinicznych (tab. XV). Poza tym u chorych z cechami nawrotu miejscowo-regionalnego bez objawów klinicznych i z prawidłowym obrazem RTG klatki piersiowej oraz prawidłowym stężeniem
LDH, TK klatki piersiowej, jamy brzusznej i miednicy ujawnia jedynie 7\% wyników prawdziwie dodatnich [111, 112]. U chorych bez objawów również badanie TK lub MR mózgu oraz PET są nieuzasadnione, biorąc pod uwagę stosunek korzyści do kosztów. W obserwacji chorych w stopniach zaawansowania IA-IIA nie ma potrzeby wykonywania badań obrazowych, natomiast można je rozważać przez pierwsze 2-3 lata (np. badanie TK klatki piersiowej) u chorych bez objawów w stopniach IIB-IIIC. Wynika to z pojawienia się w ostatnim czasie nowych, aktywnych leków w terapii rozsianych czerniaków. U chorych w stopniu zaawansowania IIIC ryzyko przerzutów do mózgu w ciągu pierwszych 13 miesięcy od miejscowego leczenia wynosi około 5\%, co może uzasadniać wykonywanie w tej grupie kontrolnego MR mózgu [103].

U chorych z klinicznymi objawami sugerującymi obecność odległych przerzutów (zaburzenia enzymów wątrobowych, bóle kości, objawy neurologiczne, kaszel i osłabienie) należy wykonać bardziej specjalistyczne badania obrazowe (TK, MR, scyntygrafia). Pojawienie się skuteczniejszych metod systemowego leczenia sprawia, że wykrywanie bezobjawowych odległych przerzutów może mieć korzystny wpływ na rokowanie.

W czasie obserwacji nie stosuje się rutynowo oznaczania surowiczych markerów, natomiast proste badania laboratoryjne (próby wątrobowe, LDH) mogą być pomocne w rzadkich przypadkach nowotworu w stopniu III i IV, kiedy pierwszym i jedynym objawem rozsiewu są ich podwyższone wartości.

\section{Mięsaki tkanek miękkich}

Celem badań kontrolnych po radykalnym leczeniu mięsaków tkanek miękkich (MTM) jest wczesne wykrywanie nawrotów choroby, których leczenie może potencjalnie przedłużyć czas przeżycia chorego. Strategia skutecznej kontroli po leczeniu choroby nowotworowej opiera się na trzech zasadach: prostych i skutecznych metodach prowadzenia obserwacji, ich dokładności oraz opłacalności ekono- 
Tabela XV. Zalecane badania kontrolne u chorych na czerniaki skóry

\begin{tabular}{|c|c|c|}
\hline Kategorie chorych & Rodzaj badania* & Częstość wykonywanych badań \\
\hline $\begin{array}{l}\text { Wczesne czerniaki (stopnie IA-IB) po wycięciu } \\
\text { ogniska pierwotnego bez przerzutów do } \\
\text { węzłów chłonnych }\end{array}$ & $\begin{array}{l}\text { Badanie przedmiotowe i podmiotowe, } \\
\text { zwłaszcza całej skóry i regionalnych węzłów } \\
\text { chłonnych oraz okolicy blizny po wyciętym } \\
\text { czerniaku**; } \\
\text { RTG klatki piersiowej — opcjonalnie; } \\
\text { Inne badania (np. USG, TK) - w przypadku } \\
\text { podejrzanych objawów; } \\
\text { USG regionalnych węzłów chłonnych - gdy } \\
\text { nie wykonano biopsji węzła wartowniczego } \\
\text { w czerniakach skóry z pT1b }\end{array}$ & $\begin{array}{l}\text { Co 6-12 mies. przez pierwsze } 5 \text { lat, } \\
\text { następnie co } 12 \text { mies. }\end{array}$ \\
\hline $\begin{array}{l}\text { Miejscowo zaawansowane czerniaki (stopnie } \\
\text { IIA-IIC) po wycięciu ogniska pierwotnego, bez } \\
\text { przerzutów do węzłów chłonnych }\end{array}$ & $\begin{array}{l}\text { Zakres badań jak w stopniu l; dodatkowo } \\
\text { w grupie chorych IIB-IIC ew. TK klatki } \\
\text { piersiowej co 6-12 mies. i raz w roku badanie } \\
\text { MR mózgu (przez pierwsze } 3 \text { lata) }\end{array}$ & $\begin{array}{l}\text { Co 3-6 mies. przez pierwsze } 2-3 \text { lata, } \\
\text { następnie co 6-12 mies. do } 5 \text { lat } \\
\text { i co } 12 \text { mies. po upływie } 5 \text { lat }\end{array}$ \\
\hline \multirow[t]{5}{*}{$\begin{array}{l}\text { Po wycięciu przerzutów do okolicznych węzłów } \\
\text { chłonnych lub miejscowej wznowy/ogniska } \\
\text { satelitarnego/in-transit (stopnie IIIA-IIIC) }\end{array}$} & $\begin{array}{l}\text { Badanie przedmiotowe i podmiotowe jak } \\
\text { w stopniu I i Il; } \\
\text { RTG klatki piersiowej; } \\
\text { Badanie morfologii i biochemii krwi (próby } \\
\text { wątrobowe i stężenie LDH); }\end{array}$ & $\begin{array}{l}\text { Co } 3 \text { mies. przez pierwsze } 2 \text { lata, } \\
\text { co } 3-6 \text { mies. przez kolejne } 3 \text { lata } \\
\text { i co } 12 \text { mies. po upływie } 5 \text { lat }\end{array}$ \\
\hline & $\begin{array}{l}\text { USG jamy brzusznej i ewentualnie okolicy po } \\
\text { usuniętych regionalnych węzłach chłonnych }\end{array}$ & \\
\hline & TK klatki piersiowej i jamy brzusznej & Co 6-12 mies. przez pierwsze 3 lata \\
\hline & MR mózgu & Co 12 mies. przez pierwsze 3 lata \\
\hline & Inne badania obrazowe & $\begin{array}{l}\text { Według indywidualnych wskazań, } \\
\text { np. podejrzenie nawrotu }\end{array}$ \\
\hline Po leczeniu przerzutów odległych (stopień IV) & $\begin{array}{l}\text { Badania obrazowe w zależności od lokalizacji } \\
\text { mierzalnych ognisk przerzutowych; } \\
\text { stężenie LDH }{ }^{* * *} \text { w surowicy }\end{array}$ & Indywidualny program wizyt kontrolnych \\
\hline
\end{tabular}

*We wszystkich stopniach edukacja chorego w kierunku samokontroli; **W stopniu T1a wyłącznie badanie przedmiotowe; ***LDH, dehydrogenaza mleczanowa

micznej $[113,114]$. Istnieje kilka propozycji standardowych zaleceń prowadzenia obserwacji po leczeniu MTM, jednak ich skuteczność została oceniona w nielicznych badaniach klinicznych [113, 115-120]. W tej sytuacji istnieją duże rozbieżności w zalecanych schematach badań kontrolnych wykonywanych w tej grupie chorych [116-119].

Szacuje się, że po leczeniu pierwotnego MTM nawrót choroby (w zależności od stopnia złośliwości histologicznej, wielkości pierwotnego nowotworu, typu histologicznego, radykalności leczenia miejscowego oraz lokalizacji) wystąpi u około $40-60 \%$ chorych $[113,117,118,121]$. Około $80 \%$ nawrotów występuje w ciągu pierwszych 3 lat po pierwszorazowym leczeniu. Lokalizacja nawrotów MTM w dużym stopniu zależy od umiejscowienia guza pierwotnego. W najczęściej występujących MTM o lokalizacji kończynowej miejscem pierwszego nawrotu są głównie przerzuty do płuc, a rzadziej (przy właściwym, skojarzonym leczeniu ogniska pierwotnego) - wznowy miejscowe. Istnieją również rzadkie podtypy MTM kończyn i tułowia, dające częściej przerzuty do węzłów chłonnych (takie jak rhabdomyosarcoma, sarcoma epithelioides, clear cell sarcoma czy sarcoma synoviale), a także do jamy brzusznej (liposarcoma myxoides). Z kolei w przypadku MTM przestrzeni zaotrzewnowej (zwłaszcza liposarcoma) lub trzewi (głównie nowotwory podścieliskowe przewodu pokarmowego, GIST) najczęściej dochodzi do nawrotów miejscowych, a w drugiej kolejności do przerzutów do wątroby.

Nawrót choroby, zwłaszcza przerzuty do odległych narządów, determinuje czas przeżycia chorych na MTM. W przypadku guzów o wysokim stopniu złośliwości około połowa chorych umiera w wyniku przerzutów. Skojarzone leczenie z udziałem chirurgii może w przypadku niektórych nawrotów MTM przynieść długoletnie przeżycie. Radykalne wycięcie przerzutów MTM do płuc pozwala znacząco wydłużyć przeżycie, zatem istotne jest wykrycie przerzutów w okresie, kiedy kwalifikują się do resekcji [119, 121, 122]. Regularne wykonywanie RTG klatki piersiowej w ponad połowie przypadków umożliwia wykrycie bezobjawowych zmian przerzutowych w płucach [113, 121, 123]. Szacuje się, że radykalne leczenie chirurgiczne przerzutów MTM ograniczonych do płuc pozwala na uzyskanie długotrwałych przeżyć u 30-40\% chorych, przy czym dotyczy to bezobjawowych klinicznie, policzalnych i mniej licznych przerzutów [122, 124-127]. Badanie RTG klatki piersiowej w ramach regularnych badań kontrolnych po leczeniu MTM pozwala na wykrycie ponad $60 \%$ przerzutów do płuc w bezobjawowej fazie. W świetle dostępnych badań wydaje się, że RTG klatki piersiowej jest wystarczające w rutynowych badaniach kontrolnych, nie ma potrzeby wykonywania TK klatki piersiowej. Wykrycie lub podejrzenie obecności zmiany w RTG klatki 
piersiowej stanowi wskazanie do wykonania TK w celu oceny liczby i lokalizacji zmian w płucach, obrazowania opłucnej, śródpiersia oraz węzłów chłonnych wnęk i śródpiersia. Według Panelu Ekspertów American College of Radiology okresowe badania TK klatki piersiowej należy rozważać jedynie u chorych na MTM o bardzo dużym ryzyku rozsiewu choroby lub po wycięciu przerzutów. Z kolei kontrola pod kątem miejscowych nawrotów powinna obejmować przede wszystkim staranne badanie przedmiotowe blizny przy zmianach łatwo dostępnych takiej ocenie, np. na kończynach czy powłokach tułowia, z ewentualnym uzupełnieniem USG [128-130]. Trzeba również zapoznać chorego z objawami miejscowych nawrotów, gdyż często są one wykrywane w ramach samokontroli. Część ekspertów zaleca również u chorych na MTM o dużym stopniu złośliwości w lokalizacji kończynowej badania USG lub MR obejmujące pierwotną lokalizację nowotworu; rutynowe wykonywanie MR jest jednak kontrowersyjne, biorąc pod uwagę skuteczność badania w stosunku do kosztów [131, 132].

Z kolei w przypadku MTM pierwotnie zlokalizowanych w przestrzeni zaotrzewnowej, śródotrzewnowo lub w okolicy pachwinowej skutecznymi metodami kontroli są badania obrazowe (spiralna TK z kontrastem lub MR) [116, 117]. Nawroty miejscowe MTM w przestrzeni zaotrzewnowej lub śródotrzewnowo są częstsze niż w lokalizacji kończynowej lub na powłokach, a ich umiejscowienie nie pozwala na wiarygodną ocenę w badaniu przedmiotowym. Mniej intensywne badania kontrolne są uzasadnione szczególnie w przypadku drugiego nawrotu MTM przestrzeni zaotrzewnowej, ponieważ nie ma dowodów, że w takim wypadku wcześniejsze wykrycie nawrotu poprawia czas przeżycia.

Brakuje standardowych zaleceń prowadzenia obserwacji po leczeniu MTM [116-119, 133-135]. Na ogół stosuje się badania kontrolne co 3-4 miesiące przez pierwsze 2-3 lata po leczeniu, następnie co 6 miesięcy przez następne 2 lata - i później raz w roku. Ryzyko nawrotu choroby zależy od stopnia złośliwości histologicznej i wielkości pierwotnego guza, radykalności leczenia skojarzonego oraz czasu, jaki upłynął od pierwotnego leczenia [116, 117, $119,121]$. Wiadomo, że w MTM o niskim stopniu złośliwości oraz wymiaru poniżej $5 \mathrm{~cm}$ ryzyko nawrotu choroby po radykalnym leczeniu jest bardzo małe. Jeśli blizna pooperacyjna jest łatwo dostępna w badaniu przedmiotowym, nie ma potrzeby wykonywania żadnych dodatkowych badań obrazowych, poza ewentualnym wykonaniem zdjęcia RTG klatki piersiowej w dwóch płaszczyznach co 6-12 miesięcy przez pierwsze 3 lata, a następnie co rok (tab. XVI). Z kolei w MTM o dużym stopniu złośliwości, w których ryzyko przerzutów do płuc oraz nawrotu miejscowego jest znacznie większe, oprócz starannego badania przedmiotowego konieczne jest cykliczne wykonywanie RTG klatki piersiowej. Uzasadnione może być także badanie obrazowe okolicy po wyciętym guzie pierwotnym [121]. Ocena regionalnych węzłów chłonnych jest celowa jedynie w wybranych podtypach MTM (np. clear cell sarcoma, sarcoma epithelioides), podobnie jak ocena jamy brzusznej (liposarcoma myxoides). Żadne stosowane dotąd badania laboratoryjne nie prowadzą do skutecznego wykrycia nawrotu mięsaków [133]. W przypadku umiejscowień trudno dostępnych badaniu przedmiotowemu, czyli przestrzeni zaotrzewnowej oraz lokalizacji śródotrzewnowej (np. GIST), należy wykonywać okresowe badanie obrazowe pod kątem nawrotu choroby. Badaniem z wyboru jest w takich przypadkach TK z podwójnym kontrastem. Wartość badania PET w schemacie badań kontrolnych po leczeniu MTM nie jest ustalona.

Chorzy na GIST powinni być poinformowani o możliwości późnego nawrotu choroby po pierwotnym leczeniu chirurgicznym $[135,136]$. W przypadku GIST o niskim stopniu agresywności badania kontrolne mogą być wykonywane raz w roku [135, 137]. Chorzy z grup o wysokim i średnim stopniu agresywności (jeżeli nie są kwalifikowani do leczenia uzupełniającego) powinni być poddani ścisłej obserwacji za pomocą TK jamy brzusznej i miednicy (z kontrastem) co 3-4 miesiące przez pierwsze 2-3 lata po resekcji pierwotnego guza (gdyż wówczas ryzyko nawrotu jest największe), następnie - do 5 lat po pierwotnej operacji - co 6 miesięcy, i po upływie 5 lat — raz w roku [134-137] (tab. XVII). Taki schemat badań klinicznych powinien być także wdrożony po zakończeniu uzupełniającego leczenia imatynibem, gdyż wówczas istnieje również zwiększone ryzyko nawrotu choroby.

Skuteczność leczenia imatynibem GIST w przypadkach zaawansowanych monitoruje się wyłącznie na podstawie wyników badania TK jamy brzusznej z kontrastem dożylnym i doustnym. Pierwsze badanie TK wykonuje się na kilka dni przed rozpoczęciem leczenia, a następne co 2 miesiące przez pierwsze pół roku terapii i później co 3-4 miesiące. U części chorych odpowiedź uzyskuje się późno (mediana 4 miesiące), a pierwszą pełną ocenę odpowiedzi na leczenie należy przeprowadzić po 4 miesiącach i po wykonaniu (co najmniej) kolejnych 2 badań kontrolnych TK. Podstawowymi ocenianymi parametrami są wymiar zmian nowotworowych według kryteriów RECIST (response evaluation criteria in solid tumors) oraz określenie gęstości zmian (tzw. kryteria Choi) [134, 135, 138]. W przypadku innych inhibitorów kinaz tyrozynowych badania obrazowe przeprowadza się zwykle co 2-3 miesiące.

Istotne jest również poinformowanie chorego, że nawroty tego nowotworu mogą występować nawet po 10 latach od pierwotnego leczenia, a w przypadku zastosowania radioterapii istnieje ryzyko rozwoju nowotworów popromiennych. 
Tabela XVI. Zalecane badania kontrolne u chorych na mięsaki tkanek miękkich (z wyłączeniem nowotworów podścieliskowych przewodu pokarmowego)

\begin{tabular}{|c|c|c|}
\hline Kategoria chorych & Rodzaj badania* & Częstość wykonywanych badań \\
\hline \multirow[t]{4}{*}{$\begin{array}{l}\text { Po radykalnym leczeniu MTM w stopniu IA-IB } \\
\text { i niski stopień złośliwości histologicznej (G1) }\end{array}$} & Badanie przedmiotowe i podmiotowe & $\begin{array}{l}\text { Co 3-6 mies. przez pierwsze } 2-3 \text { lata, } \\
\text { następnie co } 12 \text { mies. (powyżej } 10 \text { lat } \\
\text { tylko chorzy po radioterapii) }\end{array}$ \\
\hline & $\begin{array}{l}\text { RTG klatki piersiowej, TK klatki piersiowej } \\
\text { jedynie w przypadku podejrzenia zmian w RTG }\end{array}$ & Co 6-12 mies. \\
\hline & $\begin{array}{l}\text { Ew. wyjściowa ocena miejsca po resekcji za } \\
\text { pomocą badań MR, TK lub USG }\end{array}$ & 6 mies. po operacji \\
\hline & $\begin{array}{l}\text { W mięsakach przestrzeni zaotrzewnowej } \\
\text { i śródotrzewnowych TK jamy brzusznej } \\
\text { i miednicy z kontrastem (w innych } \\
\text { przypadkach badania obrazowe jedynie przy } \\
\text { klinicznym podejrzeniu wznowy) }\end{array}$ & \\
\hline $\begin{array}{l}\text { Po radykalnym leczeniu MTM w stopniu } \\
\text { II-III i/lub w wyższym stopniu złośliwości } \\
\text { histologicznej (G2/G3) lub po wycięciu } \\
\text { przerzutów do regionalnych węzłów chłonnych }\end{array}$ & $\begin{array}{l}\text { Zakres badań jak wyżej, przy czym RTG lub TK } \\
\text { klatki piersiowej przy każdej wizycie }\end{array}$ & $\begin{array}{l}\text { Co 3-4 mies. przez pierwsze } 2-3 \text { lata, } \\
\text { następnie co } 6 \text { mies. do } 5 \text { lat, potem } \\
\text { co } 12 \text { mies. }\end{array}$ \\
\hline Po leczeniu odległych przerzutów (stopień IV) & $\begin{array}{l}\text { Ocena w badaniach obrazowych w zależności } \\
\text { od lokalizacji mierzalnych ognisk } \\
\text { przerzutowych }\end{array}$ & Indywidualny program wizyt kontrolnych \\
\hline
\end{tabular}

*u wszystkich chorych edukacja w kierunku samokontroli

Tabela XVII. Zalecane badania kontrolne u chorych na nowotwory podścieliskowe przewodu pokarmowego (GIST)

\begin{tabular}{|c|c|c|}
\hline Sytuacja kliniczna & Rodzaj badania & Częstość wykonywanych badań \\
\hline $\begin{array}{l}\text { Po radykalnym leczeniu GIST o niskim i bardzo } \\
\text { niskim ryzyku nawrotu choroby (stopień I) }\end{array}$ & $\begin{array}{l}\text { Nie ma bezwzględnych wskazań do regularnej } \\
\text { kontroli, można rozważyć USG lub TK jamy } \\
\text { brzusznej i miednicy co } 12 \text { mies. Chory } \\
\text { powinien być poinformowany o istniejącym } \\
\text { niewielkim ryzyku nawrotu choroby } \\
\text { po długim czasie od leczenia }\end{array}$ & Co 12 mies. \\
\hline $\begin{array}{l}\text { Po radykalnym leczeniu GIST o pośrednim } \\
\text { ryzyku nawrotu (stopień II) }\end{array}$ & $\begin{array}{l}\text { Badanie przedmiotowe i podmiotowe, } \\
\text { TK jamy brzusznej i miednicy z kontrastem; } \\
\text { inne badania w zależności np. od lokalizacji } \\
\text { pierwotnego guza (np. MR miednicy } \\
\text { w GIST odbytnicy, TK klatki piersiowej } \\
\text { w GIST przełyku) }\end{array}$ & $\begin{array}{l}\text { Co 3-6 mies. przez pierwsze 2-3 lata, co } \\
\text { 6-12 mies. do } 5 \text { lat, następnie co } 12 \text { mies. }\end{array}$ \\
\hline $\begin{array}{l}\text { Po radykalnym leczeniu GIST o wysokim ryzyku } \\
\text { nawrotu (stopień III) }\end{array}$ & Zakres badań jak w stopniu II & $\begin{array}{l}\text { Co 3-4 mies. przez pierwsze 2-3 lata, } \\
\text { co } 6 \text { mies. do } 5 \text { lat, następnie co } 12 \text { mies. } \\
\text { (w przypadku uzupełniającego leczenia } \\
\text { imatynibem taki schemat obowiązuje od } \\
\text { zakończenia terapii) }\end{array}$ \\
\hline Po leczeniu odległych przerzutów (stopień IV) & $\begin{array}{l}\text { Badania obrazowe w zależności } \\
\text { od lokalizacji mierzalnych ognisk } \\
\text { przerzutowych (najczęściej TK } \\
\text { jamy brzusznej i miednicy) }\end{array}$ & $\begin{array}{l}\text { Program wizyt kontrolnych indywidualny } \\
\text { dla danego chorego, z reguły co } 3 \text { mies. }\end{array}$ \\
\hline
\end{tabular}

\section{Podsumowanie}

Przedstawiony materiał należy traktować jako propozycję grona ekspertów i wstęp do środowiskowej dyskusji nad stworzeniem możliwie najlepszego modelu badań kontrolnych po leczeniu chorych na nowotwory złośliwe. Finałem tego procesu powinno być opracowanie, drogą konsensusu wszystkich zainteresowanych stron, krajowych wytycznych w tej dziedzinie oraz stworzenie prawnych i finansowych warunków do ich realizacji.

Prof. dr hab. n. med. Jacek Jassem

Katedra i Klinika Onkologii i Radioterapii

Gdański Uniwersytet Medyczny

ul. Dębinki 7, 80-211 Gdańsk

e-mail:jjassem@gumed.edu.pl

Otrzymano i przyjęto do druku 15 października 2014 r. 


\section{Piśmiennictwo}

1. Kearney PL, Watkins JM, Shirai K i wsp. Salvage resection for isolated local and/or regional failure of head/neck cancer following definitive concurrent chemoradiotherapy case series and review of the literature. Mcgill J Med 2011; 13: 29.

2. Lee DH, Roh J-L, Baek S i wsp. Second cancer incidence, risk factor, and specific mortality in head and neck squamous cell carcinoma. Otolaryngol Head Neck Surg 2013; 149: 579-586.

3. Goodwin WJ Jr. Salvage surgery for patients with recurrent squamous cell carcinoma of the upper aerodigestive tract: when do the ends justify the means? Laryngoscope 2000; 110 (supl 93): 1-18.

4. Oral Care Study Group. Evidence-based management strategies for oral complication from cancer treatment. MASCC/ISOO; 2011. http:// www.mascc.org/isoo, data dostępu 10.02.2014.

5. National Comprehensive Cancer Network. Head and Neck Cancers (v. 2.2013). http://www.nccn.org/professionals/physician_ $\mathrm{gls} / \mathrm{pdf} /$ head-and-neck.pdf, data dostępu 05.05.2014.

6. Manikantan K, Khode S, Dwivedi RC i wsp. Making sense of post-treatment surveillance in head and neck cancer: when and what of follow-up. Cancer Treat Rev 2009; 35: 744-753.

7. Simo R, Homer J. Follow-up of Head and Neck Cancers. Head and neck cancer: multidisciplinary management guidelines. London: ENT-UK; 2011, s. 362-366.

8. Stupp R, Tonn JC, Brada M i wsp. High-grade malignant glioma: ESMO Clinical Practice Guidelines for diagnosis, treatment and follow-up. Ann Oncol 2010; 21 (supl. 5): v190-v193.

9. NCCN clinical practice guidelines in oncology. Central nervous system cancers, version 2.2014; ncen.org.

10. Sugimura $\mathrm{H}$, Nichols FC, Yang $\mathrm{P}$ i wsp. Survival after recurrent non-small-cell lung cancer after complete pulmonary resection. Ann Thorac Surg 2007; 83: 409-417.

11. Schmidt-Hansen $M$, Baldwin DR, Hasler E. What is the most effective follow-up model for lung cancer patients? A systematic review. J Thorac Oncol 2012; 7: 821-824.

12. Pignon JP, Stewart LA. Randomized trials of radiotherapy alone versus combined chemotherapy and radiotherapy in stages IIIa and IIIb non-small cell lung cancer: a meta-analysis. Cancer 1996; 77: 2413-2414

13. Auperin A, Le Pechoux C, Rolland E i wsp. Meta-analysis of concomitant versus sequential radiochemotherapy in locally advanced non-small cell lung cancer. J Clin Oncol 2010; 28: 2181-2190.

14. Nakamura R, Kurishima K, Kobayashi N i wsp. Postoperative follow-up for patients with non-small cell lung cancer. Onkologie 2010; 33: 14-18.

15. Korst RJ, Kansler AL., Port JL i wsp. Accuracy of surveillance computed tomography in detecting recurrent Or New primary lung cancer in patients with completely resected lung cancer. Ann Thorac Surg 2006; 82: 1009-1015.

16. Lou F, Huang J, Sima CS i wsp. Patterns of recurrence and second primary lung cancer in early-stage lung cancer survivors followed with routine computer tomography surveillance. J Thorac Cardiovasc Surg 2013; 145: 75-81.

17. Maeda R, Yoshida J, Hishida T i wsp. Late recurrence of non-small cell lung cancer more than 5 years after complete resection: incidence and clinical implications in patient follow-up. Chest 2010; 138: 145-150.

18. SugiyamaT, Hirose T, Hosaka Ti wsp. Effectiveness of intensive follow-up after response in patients with small cell lung cancer. Lung Cancer 2008; 59: 255-261.

19. Penman A, van Zandwijk N. Guidelines for the diagnosis and treatment of malignant pleural mesothelioma. Sydney: Asbestos Diseases Research Institute; 2013.

20. Feigen M, Lee ST, Lawford C i wsp. Establishing locoregional control of malignant mesothelioma using high-dose radiotherapy and (18) F-FDG PET/CT scan correlation. J Med Imag Radiat Oncol 2011; 55: 320-332.

21. Wright CD. Management of thymoma. Crit Rev Oncol Hematol 2008; 65: 109-120.

22. Huang J, Rizk NP, Travis WD i wsp. Comparison of patterns of relapse in thymic carcinoma and thymoma. JThorac Cardiovasc Surg 2009; 138:26-31.

23. Jeffery GM, Hickey BE, Hider PN. Follow-up strategies for patients treated for non-metastatic colorectal cancer. Cochrane Database Syst Rev 2007; (1): CD002200.

24. Primrose JN, Perera R, Gray A i wsp. Effect of 3 to 5 years of scheduled CEA and CT follow-up to detect recurrence of colorectal cancer: the FACS randomized clinical trial. JAMA 2014; 311: 263-270.

25. Labianca R, Nordlinger B, Beretta GD i wsp. Early colon cancer: ESMO clinical practice guidelines for diagnosis, treatment and follow-up. Ann Oncol 2013; 24 (supl. 6): vi64-vi72.
26. NCCN clinical practice guidelines in oncology. Colon cancer, version 3.2014; ncen.org.

27. Meyerhardt JA, Mangu PB, Flynn PJ i wsp. Follow-up care, surveillance protocol, and secondary prevention measures for survivors of colorectal cancer: American Society of Clinical Oncology clinical practice guideline endorsement. J Clin Oncol 2013; 31: 4465-4470.

28. NCCN clinical practice guidelines in oncology. Rectal cancer, version 3. 2014; ncen.org.

29. Glimelius B, Tiret E, Cervantes A i wsp. Rectal cancer: ESMO Clinical Practice Guidelines for diagnosis, treatment and follow-up. Ann Oncol 2013; 24 (supl. 6): vi81-vi88.

30. Khatcheressian JL, Hurley P, Bantug E i wsp. Breast cancer follow-up and management after primary treatment: American Society of Clinical Oncology clinical practice guideline update. J Clin Oncol 2013;31:961-965.

31. Senkus E, Kyriakides S, Penault-Llorca F i wsp. ESMO Clinical Practice Guidelines for diagnosis, treatment and follow-up. Ann Oncol 2013; 24 (supl. 6): vi7-vi23.

32. Rojas MP, Telaro E, Russo A i wsp. Follow-up strategies for women treated for early breast cancer. Cochrane Database Syst Rev 2005 Jan 25: CD001768.

33. Impact of follow-up testing on survival and health-related quality of life in breast cancer patients. A multicenter randomized controlled trial. The GIVIO Investigators. JAMA 1994; 271: 1587-1592.

34. Goldhirsch A, Winer EP, Coates AS i wsp. Personalizing the treatment of women with early breast cancer: highlights of the St Gallen International Expert Consensus on the Primary Therapy of Early Breast Cancer 2013. Ann Oncol 2013; 24: 2206-2223.

35. Grunfeld E, Levine MN, Julian JA i wsp. Randomized trial of long-term follow-up for early-stage breast cancer: a comparison of family physician versus specialist care. J Clin Oncol 2006; 24: 848-855.

36. Jassem J, Krzakowski M. Rak piersi. W: Krzakowski M i wsp. (red). Zalecenia postępowania diagnostyczno-terapeutycznego w nowotworach złośliwych. Gdańsk: Via Medica; 2013, 211-265.

37. Lu W, de Bock GH, Schaapveld M i wsp. The value of routine physical examination in the follow up of women with a history of early breast cancer. Eur J Cancer 2011; 47: 676-682.

38. Lash TL, Fox MP, Silliman RA. Reduced mortality rate associated with annual mammograms after breast cancer therapy. Breast J 2006; 12: 2-6.

39. Berg WA, Zhang Z, Lehrer D i wsp. Detection of breast cancer with addition of annual screening ultrasound or single screening MRI to mammography in women with elevated breast cancer risk. JAMA 2012; 307: 1394-1404.

40. Quinn EM, Coveney AP, Redmond HP. Use of magnetic resonance imaging in detection of breast cancer recurrence: a systematic review. Ann Surg Oncol 2012; 19: 3035-3041.

41. Barnsley GP, Grunfeld E, Coyle D i wsp. Surveillance mammography following the treatment of primary breast cancer with breast reconstruction: a systematic review. Plast Reconstr Surg 2007; 120: 1125-1132.

42. Smid M, Wang Y, Zhang Y i wsp. Subtypes of breast cancer show preferential site of relapse. Cancer Res 2008; 68: 3108-3114.

43. Khan QJ, Reddy PS, Kimler BF i wsp. Effect of vitamin D supplementation on serum 25-hydroxy vitamin $D$ levels, joint pain, and fatigue in women starting adjuvant letrozole treatment for breast cancer. Breast Cancer Res Treat 2010; 119: 111-118.

44. Rastelli AL, Taylor ME, Gao F i wsp. Vitamin D and aromatase inhibitor-induced musculoskeletal symptoms (AIMSS): A phase II, double-blind, placebo-controlled, randomized trial. Breast Cancer Res Treat 2011; 129: 107-116.

45. Głuszko P, Tłustochowicz W, Korkosz M. Choroby metaboliczne kości. W: Gajewski P (red.) Interna Szczeklika 2013. Podręcznik chorób wewnętrznych. Kraków: Medycyna Praktyczna; 2013, s. 1938-1947.

46. Kroenke $\mathrm{CH}, \mathrm{Chen} W Y$, Rosner B i wsp. Weight, weight gain, and survival after breast cancer diagnosis. J Clin Oncol 2005; 23: 1370-1378.

47. Holmes MD, Chen WY, Feskanich D i wsp. Physical activity and survival after breast cancer diagnosis. JAMA 2005; 293: 2479-2486.

48. Holmberg L, Anderson H; HABITS steering and data monitoring committees. HABITS (hormonal replacement therapy after breast cancer - is it safe?), a randomized comparison: trial stopped. Lancet 2004; 363: 453-455.

49. Zhao S, Chlebowski RT, Anderson GL i wsp. Sex hormone associations with breast cancer risk and the mediation of randomized trial postmenopausal hormone therapy effects. Breast Cancer Res 2014; 16: R30.

50. Moegele M, Buchholz S, Seitz S i wsp. Vaginal estrogen therapy for patients with breast cancer. Geburtshilfe Frauenheilkd 2013; 73: 1017-1022. 
51. Le Ray I, Dell'Aniello S, Bonnetain F i wsp. Local estrogen therapy and risk of breast cancer recurrence among hormone-treated patients: a nested case-control study. Breast Cancer Res Treat 2012; 135:603-609.

52. Salani R, Backes FJ, Fung MF i wsp. Posttreatment surveillance and diagnosis of recurrence in women with gynecologic malignancies: Society of Gynecologic Oncologists recommendations. Am J Obstet Gynecol 2011; 204: 466-478.

53. http://www.nccn.org/professionals/physician_gls/pdf/uterine.pdf

54. http://www.ncen.org/professionals/physician_gls/pdf/cervical.pdf.

55. http://www.nccn.org/professionals/physician_gls/pdf/ovarian.pdf.

56. Rustin GJ, van der Burg ME, Griffin CL i wsp. Early versus delayed treatment of relapsed ovarian cancer. Lancet 2010; 376: 9747: 1155-1163.

57. Colombo N, Carinelli S, Colombo A i wsp. Cervical cancer: ESMO Clinical Practice Guidelines for diagnosis, treatment and follow-up. Ann Oncol 2012; 23 (supl. 7): 27-32.

58. Ledermann JA, Raja FA, Fotopoulou C i wsp. Newly diagnosed and relapsed epithelial ovarian carcinoma: ESMO Clinical Practice Guidelines for diagnosis, treatment and follow-up. Ann Oncol 2013; 24 (supl. 6): 24-32.

59. Colombo N, Preti E, Landoni F i wsp. Endometrial cancer: ESMO Clinical Practice Guidelines for diagnosis, treatment and follow-up. Ann Oncol 2013; 24 (supl. 6): 33-38.

60. Fung-Kee-Fung $M$, Dodge J, Elit L i wsp. Follow-up after primary therapy for endometrial cancer: a systematic review. Gynecol Oncol 2006; 101: 520-529.

61. du Bois A, Reuss A, Pujade-Lauraine E i wsp. Role of surgical outcome as prognostic factor in advanced epithelial ovarian cancer: a combined exploratory analysis of 3 prospectively randomized phase 3 multicenter trials: by the Arbeitsgemeinschaft Gynaekologische Onkologie Studiengruppe Ovarialkarzinom (AGO-OVAR) and the Groupe d'Investigateurs Nationaux Pour les Etudes des Cancers de I'Ovaire (GINECO). Cancer 2009; 115: 1234-1244.

62. Gadducci A, Fuso L, Cosio S i wsp. Are surveillance procedures of clinical benefit for patients treated for ovarian cancer?: A retrospective Italian multicentric study. Int J Gynecol Cancer 2009; 19: 367-374.

63. De Gregorio N, Baumann KH, Keyver-Paik MD i wsp. Outcome of patients with borderline ovarian tumors: Results of the multicenter AGO ROBOT study. J Clin Oncol 2012; 30 (supl); abstr 5005.

64. Zanetta G, Rota S, Lissoni A i wsp. Ultrasound, physical examination, and CA125 measurement for the detection of recurrence after conservative surgery for early borderline ovarian tumors. Gynecol Oncol 2001; 81: 63-66.

65. Kane A, Uzan C, Rey A i wsp. Prognostic factors in patients with ovarian serous low malignant potential (borderline) tumors with peritoneal implants. Oncologist 2009; 14: 591-600.

66. Schumer ST, Cannistra SA. Granulosa cell tumor of the ovary. J Clin Oncol 2003; 21: 1180-1189.

67. Gershenson DM. Management of ovarian germ cell tumor. J Clin Oncol 2007; 25: 2938-2943.

68. Elit L, Fyles AW, Oliver TK i wsp. Follow-up for women after treatment for cervical cancer. Curr Oncol 2010; 17: 65-69.

69. Zanagnolo V, Ming L, Gadducci A i wsp. Surveillance procedures for patients with cervical carcinoma: a review of the literature. Int J Gynecol Cancer 2009; 19: 194-201.

70. Brooks RA, Rader JS, Dehdashti F i wsp. Surveillance FDG-PET detection of asymptomatic recurrences in patients with cervical cancer. Gynecol Oncol 2009; 112: 104-109.

71. Gonzalez Bosquet J, Magrina JF, Gaffey TA i wsp. Long-term survival and disease recurrence in patients with primary squamous cell carcinoma of the vulva. Gynecol Oncol 2005; 97: 828-833.

72. Tantipalakorn C, Robertson G, Marsden DE i wsp. Outcome and patterns of recurrence for International Federation of Gynecology and Obstetrics (FIGO) stages I and II squamous cell vulvar cancer. Obstet Gynecol 2009; 113: 895-901.

73. Shen S, Lepor H, Yaffee R i wsp. Ultrasensitive serum prostate specific antigen nadir accurately predicts the risk of early relapse after radical prostatectomy. J Urol 2005; 173: 777-780.

74. Eisenberg ML, Davies BJ, Cooperberg MR i wsp. Prognostic implications of an undetectable ultrasensitive prostate-specific antigen level after radical prostatectomy. Eur Urol 2010; 57: 622-629.

75. Roach III M, Hanks G, Thames H Jr i wsp. Defining biochemical failure following radiotherapy with or without hormonal therapy in men with clinically localized prostate cancer: recommendations of the RTOG-ASTRO Phoenix Consensus Conference. Int J Radiat Oncol Biol Phys 2006; 65: 965-974.
76. Stamey TA, Kabalin JN, McNeal JE i wsp. Prostate specific antigen in the diagnosis and treatment of adenocarcinoma of the prostate. II. Radical prostatectomy treated patients. J Urol 1989; 141: 1076-1083.

77. Partin AW, Pearson JD, Landis PK i wsp. Evaluation of serum prostate-specific antigen velocity after radical prostatectomy to distinguish local recurrence from distant metastases. Urology 1994; 43: 649-659.

78. Ray ME, Thames HD, Levy LB i wsp. PSA nadir predicts biochemical and distant failures after external beam radiotherapy for prostate cancer: a multi-institutional analysis. Int J Radiat Oncol Biol Phys 2006; 64: $1140-1150$.

79. Hancock SL, Cox RS, Bagshaw MA. Prostate specific antigen after radiotherapy for prostate cancer: a reevaluation of long-term biochemical control and the kinetics of recurrence in patients treated at Stanford University. J Urol 1995; 154: 1412-1417.

80. Oefelein MG, Smith N, Carter M i wsp. The incidence of prostate cancer progression with undetectable serum prostate specific antigen in a series of 394 radical prostatectomies. J Urol 1995; 154: 2128-2131.

81. Kattan MW, Reuter V, Motzer RJ i wsp. A postoperative prognostic nomogram for renal cell carcinoma. J Urol 2001; 166: 63-67.

82. Lam JS, Shvarts O, Leppert JT i wsp. Postoperative surveillance protoco for patients with localized and locally advanced renal cell carcinoma based on a validated prognosticated nomogram and risk group stratification system. J Urol 2005; 174: 466-472.

83. Leibovich BC, Blute ML, Cheville JC i wsp. Prediction of progression after radical nephrectomy for patients with clear cell renal cell carcinoma: a stratification tool for prospective clinical trials. Cancer 2003; 97: $1663-1671$.

84. Karakiewicz PI, Briganti A, Chun FK i wsp. Multi-institutional validation of a new renal cancer-specific survival nomogram. J Clin Oncol 2007; 25: 1316-1322.

85. Bellmunt J, Orsola A, Leow JJ i wsp. Bladder cancer: ESMO Practice Guidelines for diagnosis, treatment and follow-up. Ann Oncol 2014; 25 (suppl 3): 40-48.

86. Albers P, Albrecht W, Algaba F i wsp. Guidelines on Testicular Cancer. European Urology 2011; 60: 304-319.

87. Pizzocaro G, Algaba F, Horenblas S i wsp. EAU Penile Cancer Guidelines. Eur Urol 2010; 57: 1002-1012.

88. Francken $A B$, Hoekstra HJ. Follow-up of melanoma patients: the need for evidence-based protocols. Ann Surg Oncol 2009; 16: 804-805.

89. Fields RC, Coit DG. Evidence-based follow-up for the patient with melanoma. Surg Oncol Clin N Am 2011; 20: 181-200.

90. Scally CP, Wong SL. Intensity of follow-up after melanoma surgery. Ann Surg Oncol 2014; 21: 752-757.

91. Weiss M, Loprinzi CL, Creagan ET i wsp. Utility of follow-up tests for detecting recurrent disease in patients with malignant melanomas. JAMA 1995; 274: 1703-1705.

92. Dummer R, Hauschild A, Guggenheim M i wsp. Cutaneous melanoma: ESMO Clinical Practice Guidelines for diagnosis, treatment and follow-up. Ann Oncol 2012; 23: vii86-vii91.

93. NCCN Clinical Practice Guidelines in Oncology. Melanoma v.2. 2014.

94. Garbe C, Hauschild A, Volkenandt M i wsp. Evidence and interdisciplinary consense-based German guidelines: diagnosis and surveillance of melanoma. Melanoma Res 2007; 17: 393e9.

95. Johnson TM, Bradford CR, Gruber SB i wsp. Staging workup, sentinel node biopsy, and follow-up tests for melanoma: update of current concepts. Arch Dermatol 2004; 140: 107-113.

96. Rutkowski P, Wysocki PJ, Nowecki Zl i wsp. Czerniaki skóry — zasady postępowania diagnostyczno-terapeutycznego w 2013 roku. Onkol Prakt Klin 2012; 8: 178-192.

97. Christianson DF, Anderson CM. Close monitoring and lifetime follow-up is optimal for patients with a history of melanoma. Semin Oncol 2003; 30: 369-374.

98. Francken $A B$, Bastiaannet $E$, Hoekstra HJ. Follow-up in patients with localised primary cutaneous melanoma. Lancet Oncol 2005; 6: 608-621.

99. Francken AB, Shaw HM, Accortt NA i wsp. Detection of first relapse in cutaneous melanoma patients: implications for the formulation of evidence-based follow-up guidelines. Ann Surg Oncol 2007; 14: 1924-1933.

100. Francken AB, Accortt NA, Shaw HM i wsp. Follow-up schedules after treatment for malignant melanoma. Br J Surg 2008; 95: 1401-1407.

101. Garbe C, Paul A, Kohler-Spath H i wsp. Prospective evaluation of a follow-up schedule in cutaneous melanoma patients: recommendations for an effective follow-up strategy. J Clin Oncol 2003; 21: 520-529.

102. Meyers MO, Yeh JJ, Frank J i wsp. Method of detection of initial recurrence of stage II/III cutaneous melanoma: analysis of utility of follow-up staging. Ann Surg Oncol 2009; 16: 941-947. 
103. Romano E, Scordo M, Dusza SW i wsp. Site and timing of first relapse in stage III melanoma patients: implications for follow-up guidelines. J Clin Oncol 2010; 28: 3042-3047.

104. Rueth NM, Xing Y, Chiang YJ i wsp. Is surveillance imaging effective for detecting surgically treatable recurrences in patients with melanoma? A comparative analysis of stage-specific surveillance strategies. Ann Surg 2014; 259:1215-1222.

105. Turner RM, Bell KJ, Morton RL i wsp. Optimizing the frequency of follow-up visits for patients treated for localized primary cutaneous melanoma. J Clin Oncol 2011; 29: 4641-4646.

106. Autier $\mathrm{P}$, Coebergh JW, Boniol M i wsp. Management of melanoma patients: benefit of intense follow-up schedule is not demonstrated. J Clin Oncol 2003; 21: 3707-3708.

107. Rychetnik L, McCaffery K, Morton RL i wsp. Follow-up of early stage melanoma: specialist clinician perspectives on the functions of follow-up and implications for extending follow-up intervals. J Surg Oncol 2013; 107: 463-468.

108. Einwachter-Thompson J, MacKie RM. An evidence base for reconsidering current follow-up guidelines for patients with cutaneous melanoma less than $0.5 \mathrm{~mm}$ thick at diagnosis. Br J Dermatol 2008; 159: 337-341.

109. Balfounta ML, Beauchet A, Chagnon S i wsp. Ultrasonography or palpation for detection of melanoma nodal invasion: a meta-analysis. Lancet Oncol 2004; 5: 673-680.

110. Voit C, Mayer T, Kron M i wsp. Efficacy of ultrasound B-scan compared with physical examination in follow-up of melanoma patients. Cancer 2001; 91: 2409-2416.

111. Morton RL, Craig JC, Thompson JF. The role of surveillance chest x-rays in the follow-up of high-risk melanoma patients. Ann Surg Oncol 2009; 16: 571-577.

112. Tsao H, Feldman M, Fullerton JE i wsp. Early detection of asymptomatic pulmonary melanoma metastases by routine chest radiographs is not associated with improved survival. Arch Dermatol 2004; 140: 67-70.

113. Cool P, Grimer R, Rees R. Surveillance in patients with sarcoma of the extremities. Eur J Surg Oncol 2005; 31: 1020-1024.

114. Goel A, Christy M, Virgo K i wsp. Costs of follow-up after potentially curative treatment for extremity soft-tissue sarcoma. Int J Oncol 2004; 25: 429-435.

115. Gerrand $\mathrm{CH}$, Billingham LJ, Woll PJ i wsp. Follow-up after primary treatment of soft tissue sarcoma: a survey of current practice in the United Kingdom. Sarcoma 2007, Article ID 34128.

116. Soft tissue and visceral sarcomas: ESMO Clinical Practice Guidelines for diagnosis, treatment and follow-up. The ESMO/European Sarcoma Network Working Group. Ann Oncol 2012; 23 (supl. 7): vii92-vii99.

117. National Comprehensive Cancer Network Clinical Practice Guidelines in Oncology, Soft Tissue Sarcomas, Version 1.2013.

118. Grimer R, Judson I, Peake D i wsp. Guidelines for the management of soft tissue sarcomas. Sarcoma 2010, Article ID 506182.

119. Ruka W, Rutkowski P, Krzakowski M i wsp. Mięsaki tkanek miękkich u dorosłych — zasady postępowania diagnostyczno-terapeutycznego. Nowotwory J Oncol 2010; 60: 55-65.

120. Sakata K, Beitler AL, Gibbs JF i wsp. How surgeon age affects surveillance strategies for extremity soft tissue sarcoma patients after potentially curative treatment. J Surg Res 2002; 108: 227-234.
121. Chou YS, Liu CY, Chen WM i wsp. Follow-up after primary treatment of soft tissue sarcoma of extremities: impact of frequency of follow-up imaging on disease-specific survival. J Surg Oncol 2012; 106: 155-161.

122. Van Geel AN, Pastorini U, Jauch KW i wsp. The surgical treatment of lung metastases. The European Organization for Research and Treatment of Cancer - Soft Tissue and Bone Sarcoma Group study of 255 patients. Cancer 1996; 77: 675-682.

123. Patel SR, Zagars GK, Pisters PWT. The follow-up of adult soft tissue sarcomas. Sem Surg Oncol 2003; 30: 413-416.

124. Casson AG, Putnam JB, Natarajan G i wsp. Five-years survival after pulmonary metastasectomy for adult soft tissue sarcoma. Cancer 1992; 69: 662-668.

125. Gadd MA, Casper ES, Woodruff JM i wsp. Development and treatment of pulmonary metastases in adult patients with extremity soft tissue sarcoma. Ann Surg 1993; 218: 705-712.

126. Whooley BP, Gibbs JF, Mooney MM i wsp. Primary extremity sarcoma: What is the appropriate follow-up? Ann Surg Oncol 2000; 7: 9-14.

127. Whooley BP, Mooney MM, Gibbs JF i wsp. Effective follow-up strategies in soft tissue sarcoma. Sem Surg Oncol 1999; 17: 83-87.

128. Choi H, Varma DG, Fornage BD i wsp. Soft-tissue sarcoma: MR imaging vs sonography for detection of local recurrence after surgery. AJR Am J Roentgenol 1991; 157: 353-358.

129. Arya S, Nagarkatti DG, Dudhat SB i wsp. Soft tissue sarcomas: ultrasonographic evaluation of local recurrences. Clin Radiol 2000; 55: 193-197.

130. Briccoli A, Galletti S, Salone M i wsp. Ultrasonography is superior to computed tomography and magnetic resonance imaging in determining superficial resection margins of malignant chest wall tumors. J Ultrasound Med 2007; 26: 157-162.

131. Labarre D, Aziza R, Filleron T i wsp. Detection of local recurrences of limb soft tissue sarcomas: Is magnetic resonance imaging (MRI) relevant? Eur J Radiol 2009; 72: 50-53.

132. Vanel D, Shapeero LG, De Baere T i wsp. MR imaging in the follow-up of malignant and aggressive soft-tissue tumors: results of 511 examinations. Radiology 1994; 190: 263-268.

133. Brennan MF. Follow-up is valuable and effective: true, true and unrelated? Ann Surg Oncol 2000; 7: 2-3.

134. Casali PG, Jost L, Reichardt P i wsp. Gastrointestinal stromal tumors: ESMO clinical recommendations for diagnosis, treatment and follow-up. Ann Oncol 2009; 20 (supl. 4): 64-67.

135. Rutkowski P, Kulig J, Krzakowski M i wsp. Zasady postępowania diagnostyczno-terapeutycznego u chorych na nowotwory podścieliskowe przewodu pokarmowego (GIST) w 2010 roku. Onkol Prakt Klin 2010; 6: 181-194.

136. Rutkowski P, Wozniak A, Dębiec-Rychter M i wsp. Clinical utility of the new American Joint Committee on Cancer staging system for gastrointestinal stromal tumors: Current overall survival after primary tumor resection. Cancer 2011; 117: 4916-4924.

137. Joensuu H., Eriksson M., Sundby Hall K i wsp. One vs three years of adjuvant imatinib for operable gastrointestinal stromal tumor: a randomized trial. JAMA 2012; 307: 1265-1272.

138. Reichardt $\mathrm{P}$, Blay JY, von Mehren M. Towards global consensus in the treatment of gastrointestinal stromal tumor. Expert Rev Anticancer Ther 2010; 10: 221-232. 